\title{
The Impacts of Interest Rate Changes on US Midwest Farmland Values
}

\author{
Albulena Basha, Wendong Zhang, Chad Hart \\ Working Paper 21-WP 614 \\ January 2021 \\ Center for Agricultural and Rural Development \\ lowa State University \\ Ames, lowa 50011-1070 \\ www.card.iastate.edu
}

Albulena Basha is Junior Advisor, Deutsche Gesellschaft für Internationale Zusammenarbeit (GIZ) GmbH. E-mail: basha.albulena@gmail.com.

Wendong Zhang is Assistant Professor, Center for Agricultural and Rural Development, lowa State University, Ames, IA 50011-1070. E-mail: wdzhang@iastate.edu.

Chad Hart is Professor, Center for Agricultural and Rural Development, lowa State University, Ames, IA 50011-1070. E-mail: chart@iastate.edu

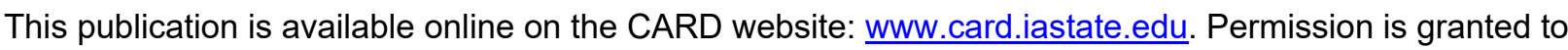
reproduce this information with appropriate attribution to the author and the Center for Agricultural and Rural Development, lowa State University, Ames, lowa 50011-1070.

For questions or comments about the contents of this paper, please contact Wendong Zhang, wdzhang@iastate.edu.

lowa State University does not discriminate on the basis of race, color, age, ethnicity, religion, national origin pregnancy, sexual orientation, gender identity, genetic information, sex, marital status, disability, or status as a U.S. veteran. Inquiries regarding non-discrimination policies may be directed to Office of Equal Opportunity, 3410 Beardshear Hall, 515 Morrill Road, Ames, lowa 50011, Tel. (515) 294-7612, Hotline: (515) 294-1222, email eooffice@iastate.edu. 


\title{
The Impacts of Interest Rate Changes on US Midwest Farmland Values
}

\author{
Albulena Basha \\ Junior Advisor \\ Deutsche Gesellschaft für Internationale Zusammenarbeit (GIZ) GmbH \\ Email:basha.albulena@gmail.com \\ Wendong Zhang \\ Assistant Professor \\ Department of Economics and Center for Agricultural and Rural Development \\ Iowa State University, Email:wdzhang@iastate.edu

\section{Chad Hart} \\ Professor \\ Department of Economics and Center for Agricultural and Rural Development \\ Iowa State University, Email:chart@iastate.edu
}

Date: January 9, 2021

\section{Forthcoming at Agricultural Finance Review}

Acknowledgements: The authors thank Nathan Cook, Helen Jensen, Michael Duffy, and Nathan Cook for comments on an earlier draft. Zhang and Hart gratefully acknowledge support from the USDA National Institute of Food and Agriculture Hatch Project 101,030 and 1020548, Basha acknowledges support from the Kosovo American Education Fund.

Disclaimer: The views in this paper are the author's only and they do not represent the views of GIZ. 


\section{Structured Abstract (250 Words Max)}

Purpose: Our paper quantifies the effects of recent Federal Reserve interest rate changes, specifically recent hikes and cuts in the federal funds rate since 2015, on Midwest farmland values.

Methodology: We apply three autoregressive distributed lag models to a panel data of state-level farmland values from 1963 to 2018 to estimate the dynamic effects of interest rate changes on the US farmland market. We focus on the I-states, Lakes states and Great Plains states. Our models capture both short-term and long-term impacts of policy changes on land values. Findings: We find that changes in the federal funds rate have long-lasting impacts on farmland values, as it takes at least a decade for the full effects of an interest rate change to be capitalized in farmland values. Our results show that the three recent federal funds rate cuts in 2019 were not sufficient to offset the downward pressures from the 2015-2018 interest rate hikes, but the 2020 cut is. The combined effect of the Federal Reserve's recent interest rate moves on farmland values will be positive for some time starting in 2022 .

Originality and Policy Implications: Our paper provides the first empirical quantification of the immediate and long-run impacts of recent Federal Reserve interest rate moves on farmland values. We demonstrate the long-lasting repercussions of Federal Reserve's policy choices in the farmland market.

Article Classification: Research Article

Keywords: Farmland; Interest Rate; Federal Reserve; Autoregressive Distributed Lag Model;

Federal Funds Rate; Land Value

JEL Codes: Q14, G28 


\section{Introduction}

Buoyed by strong agricultural exports, historically low interest rates, and added demand from ethanol production, US Midwest farmland values skyrocketed from 2003 to 2013 along with significant growth in farm income (Zhang and Tidgren, 2018). However, since the drought of 2012, the US agricultural economy has suffered through a significant decline — net farm income fell by roughly 50\% from 2013 to 2016 and farm debts rose dramatically. Even with the recent forecasted bump in 2020 farm sector profits and record-level government support, the inflationadjusted US net farm income in 2020 will still be 13\% below its 2013 peak (USDA-ERS, 2020). The stability of farm assets is one factor supporting the farm balance sheet. As farmland constitutes the overwhelming majority of farm assets, it is considered the most important asset in farmers' and landowners' overall investment portfolios and serves as robust collateral on which agricultural lenders make lending decisions. Despite a third modest rise over the past six years, the 2020 Iowa land value still represents a 13\% decline from the 2013 peak in nominal land values, or a $22 \%$ drop in inflation-adjusted values (Zhang, 2020). Given that farmland is a critical asset in the agricultural economy that affects multiple parties, its value is an important indicator of the agricultural economy. Compared to the drastic cuts in farm income, the farmland market is somewhat surprisingly resilient—agricultural professionals frequently mentioned favorable interest rates as one of the most important factors supporting land values.

The evolution and determinants of farmland values have been extensively studied in agricultural finance and management literature, and such determinants include both economic and non-economic factors (Nickerson and Zhang, 2014), including net farm income (Featherstone et al., 2017). However, at least three factors have generated significant renewed interest in the trajectory of farmland price movements: $(a)$ recent interest rate shifts in both 
directions by the US Federal Reserve, which resulted in interest rates rising from historically low levels to the highest levels since 2008, followed by a surprising decline; $(b)$ agricultural trade disputes with key trading partners have already led to lower commodity prices, which should negatively impact future farm income and, consequently, farmland values; and, (c) the significant uncertainty resulting from the ongoing COVID-19 pandemic and record-level ad-hoc government payments for farmers, which further elevated the stabilizing role of farmland values for the agricultural sector. In particular, the Federal Reserve stopped raising the federal funds rate in 2019, reversing its rate hikes since late 2015, and implemented drastic cuts in March 2020 in response to the COVID-19 pandemic. This effectively reduced this key benchmark interest rate from $2.25 \%$ one year prior to only $0.25 \%$. With USDA's long-term projections showing continued weakness in commodity returns, the stability of the farm balance sheet will depend on the shifts in land values. The mixed signals from the interest rate changes from the Federal Reserve and the ongoing uncertainty in trade policies highlight the fluidity of asset values.

In general, interest rates inversely correlate with farmland values. At lower interest rates, demand for farm loans increases due to lower interest payments, signaling lower returns on competing assets, thereby leading to a higher demand for land (Zhang and Tidgren, 2018). Previous literature examines the effects of interest rates, land returns or cash rents, and inflation in explaining the variation in farmland values (e.g., Lence, 2014; Moss, 1997; Falk, 1991; Featherstone and Baker, 1987). Furthermore, Sherrick (2018) argues descriptively that low interest rates are the primary driver of resilience for farmland values despite the divergence from farm income levels. The federal funds rate is the primary policy instrument of the Federal Reserve and the only interest rate set by policymakers. Previous literature in monetary economics establishes that both short-term and long-term market interest rates respond to 
changes in the federal funds rate (e.g., Cook and Hahn, 1989; Kuttner, 2001; Thornton, 1998; Romer and Romer, 2000). However, there lacks systematic evaluation of the impacts of recent interest rate changes over the past five years on farmland values.

The objective of this article is to provide the first quantification of the impacts federal policies, specifically the recent changes in interest rates since 2015 , have on farmland values. To do this, we use three autoregressive distributed lag (ARDL) models and a panel data of statelevel farmland values from 1963 to 2018 to estimate the dynamic effects of interest rate changes on the US farmland market. We apply this model to 12 Midwestern states in three regions (the Istates, Lakes states, and Great Plains states) using annual, state-level data for farmland values, real interest rates, gross farm income, and interest expense for real estate. Following De Boef and Keele (2008), our models not only capture the short-term effects of policy changes, but also show the longer-term impacts of policy changes on land values by quantifying the median lag length and long-run multiplier effects due to changes in inflation-adjusted interest rates.

Our main results confirm the inverse relationship between land values and interest rates, and, more importantly, show that the effects of interest rate changes on farmland values span multiple years. In particular, the median lag length analysis shows that it takes between 6-18 years for the farmland market to capitalize on half of the total cumulative effect of interest rate changes. In addition, our results show that the effect of interest rates peak in the second and third year following a change, while the contemporary effects of farm income changes on land values are much larger. Our finding of long-lasting impacts of interest rate changes suggest that the cuts in the federal funds rate in 2019 only partially offset the downward pressures resulting from the interest rate hikes from 2015-2018. However, our projection assuming no further changes in interest rates after 2020 suggests that the recent cuts in 2020 will offset the impact of previous 
hikes by 2022. Before the 2020 decline in interest rates, researchers anticipated the Federal Reserve's interest rate changes would have a negative overall effect on farmland values for the next few years. However, the combined effect of the Federal Reserve's recent interest rate moves on farmland values will be positive, starting in 2022, and will continue to be positive for some time. In fact, the decline from 2020 will still be the interest rate change in effect today with the largest impact on 2025 farmland values.

Our article provides a timely analysis on an important policy relevant question—what is the effect of recent interest rate hikes and cuts made by the Federal Reserve on US farmland values? We not only conceptually demonstrate the long-lasting impact of interest rate changes on land values by plotting its temporal capitalization pattern using the median lag length analysis, but also analyze the capitalization path of the 2015-2018 federal funds rate hikes and the cuts in 2019-2020 and beyond. Overall, we find that the 2019 interest rate cuts can only offset about one-seventh of the downward pressures resulting from the 2015-2018 federal funds rate hikes; however, the 2020 interest rate cuts will more than offset the downward pressures from 20152018 hikes, highlighting the long-lasting repercussions of the Federal Reserve's choices in the farmland market.

\section{Conceptual Framework}

The present value model is a workhorse model that examines agricultural land values (e.g., Burt, 1986; Weersink et al., 1999; Goodwin et al., 2003; Shaik et al., 2005). The model posits that the current value of a farmland parcel at year $t$ is the sum of expected future land returns discounted to the risk of the returns or the capitalized value of the future income streams from owning this land parcel. The common specification is: 


$$
Y_{t}=\sum_{i=0}^{\infty} \frac{E\left(R_{t+i}\right)}{\left(1+r_{t+1}\right)\left(1+r_{t+2}\right) \ldots\left(1+r_{t+i}\right)}
$$

where $Y_{t}$ is the equilibrium farmland values in year $\mathrm{t} ; R_{t+i}$ is the real future net return generated from owning farmland in year $t+i ; r_{t+i}$ is the time-varying real discount rate in year $t+i$; and, $E$ is the expectation on returns conditional on information in period $\mathrm{t}$.

Assuming the constant expected returns $R^{*}$, risk neutral agents, ignoring differential tax treatments of capital gains and rental income, and discounting them over an infinite life, we can simplify equation (1) to the traditional capitalization formula:

$$
Y_{t}=\frac{R^{*}}{r}
$$

Melichar (1979) recognizes the real capital gains in current returns to farm assets and modifies the capitalization formula to account for the growth of current return. Burt (1986), in a separately dynamic multiplicative distributed lag specification on net returns and assuming a constant real rate of interest, specifies the farmland value as a dynamic regression:

$$
Y_{t}=\left(\alpha R_{t}^{\beta_{0}} R_{t-1}^{\beta_{1}} R_{t-2}^{\beta_{2}} \ldots\right) u_{t}
$$

where $u_{t}$ is a random disturbance; and, the $\left\{\beta_{j}\right\}$ are unknown parameters, which are constrained to sum to one to be consistent with the Ricardian framework shown in equation (1). We could show that by taking natural logarithms, empirically, farmland value at year $t$ could be a function of current and lagged net returns, as well as lagged farmland values in previous years.

Finally, many recent studies of farmland prices (e.g., Weersink et al., 1999; Goodwin et al., 2003; Zhang and Nickerson, 2015) focus on the demand factors that drive farmland values and further decompose net returns into returns from crop or livestock production, government 
payments, or earnings from recreational benefits or future urban development potential. In this article, we do not separate government payments from agricultural income, but instead focus on the capitalization effects of interest rates.

\section{Data}

Data are obtained from three sources and consist of annual, state-level data from 1963 to 2018 for 12 Midwestern states in three different regions, based on similarities in production mix, geographical proximity, and land quality: (a) I-states_-Illinois, Iowa, and Indiana; (b) Lakes states-Ohio, Michigan, Minnesota, and Wisconsin; and, (c) Great Plains states-Missouri, Kansas, Nebraska, and North and South Dakota. We derive farmland value data from USDA's National Agricultural Statistics Service (NASS) Quick Stats and obtain gross farm income and interest expense for real estate data from USDA's Economic Research Service (ERS) Farm Income and Wealth Statistics Database. We obtain average annual interest rate data, such as the federal funds rate and the US Treasury one-year or 10-year constant maturity rates, from the St. Louis Federal Reserve Economic Data (St. Louis FRED). In addition, we take 20-year-fixed farm real estate mortgage rates for robustness checks from the Federal Reserve Banks of Chicago and Kansas City. As mentioned earlier, the federal funds rate is the primary policy instrument of the Federal Reserve and the only interest rate set by policymakers; and thus, our main results rely on federal funds rate and use other market interest rates mainly for robustness checks. We adjust farmland value obtained from the US Bureau of Labor Statistics for inflation using the Consumer Price Index (base year $=2019$ ). We use farm income, instead of cash rent, because the USDA state-level cash rent data is only available starting in 1994 and only captures cash rent for cropland, whereas our farmland value is based on agricultural real estate values that include 
pastureland and timberland, as well as buildings, in addition to cropland. Table I displays the summary statistics.

[Insert Table 1 Here]

\section{Empirical Model}

As opposed to choosing one particular specification, as in Burt (1986), we follow De Boef and Keele (2008) and use generalized ARDL models. The farmland value equation by Shaik et al. (2005) and Goodwin et al. (2003) is a restrictive form of this model that assumes no influences of lagged farmland prices, net returns, or previous interest rate changes, which is a rather significant assumption. Weersink et al.'s (1999) model differs from ours in that it only includes a lagged farm income variable, ignoring the dynamic evolution of interest rate changes.

Specifically, we derive three ARDL models (one for each region) using the state-level, inflation-adjusted farmland value from 1963 to 2018 as the dependent variable. The regressors include state-level, inflation-adjusted gross farm income and nationwide inflation-adjusted interest rate, as well as one lag of each of the independent variables. We employ the federal funds rate as the main interest rate for this study as it is the only interest rate officially set as a policy target (Cook and Hahn, 1989). We use 10-year and one-year US Treasury constant maturity rates and farm real estate loan rates as robustness checks. Figure 1 shows that the various market interest rates move correspondingly as the Federal Reserve moves the federal funds rate. We address serial correlation by adding the lag of the dependent variable (Featherstone et al., 2017), and we estimate robust standard errors to control for heteroscedasticity of the error terms. The model controls for a linear trend and state fixed effects to account for unobserved heterogeneity within the groups. Farmland values and gross farm 
income data are log-transformed to smooth variability and stationarity and transform skewed data into a normal distribution.

\section{[Insert Figure 1]}

We follow the general form of the derived models of an ARDL (p,q;n), specified in equation (4), where $p$ is the number of lags of $Y_{i, t}, q$ is the number of lags of $\boldsymbol{X}_{i, t}$, and $n$ is the number of the independent regressors (Bardsen, 1989; De Boef and Keele, 2008).

$$
\mathrm{Y}_{\mathrm{i}, \mathrm{t}}=\alpha_{0}+\sum_{\mathrm{k}=1}^{\mathrm{p}} \alpha_{\mathrm{k}} \mathrm{Y}_{\mathrm{i}, \mathrm{t}-\mathrm{k}}+\sum_{\mathrm{m}=0}^{\mathrm{n}} \boldsymbol{\beta}_{\mathrm{m}} \mathbf{X}_{\mathrm{i}, \mathrm{t}-\mathbf{m}}+\delta_{\mathrm{i}}+t+\epsilon_{\mathrm{i}, \mathrm{t}}
$$

where $Y_{i, t}$ is the $\log$ of inflation-adjusted farmland value for state $i$ and year $t$; and, the vectors $\boldsymbol{X}_{\boldsymbol{i}, \boldsymbol{t}}$ and $\boldsymbol{X}_{\boldsymbol{i}, \boldsymbol{t}-\mathbf{1}}$ represent the contemporaneous and lagged inflation-adjusted federal funds rate, the log of inflation-adjusted gross farm income, and the log of inflation-adjusted interest rate expense for real estate. In addition, the Hausman test suggests that the fixed effects model is more appropriate for this dataset than the random effects model, and thus we include $\delta_{i}$, which is the time-invariant individual state fixed effect. In addition, $t$ accounts for a linear trend, and $\epsilon_{i, t}$ is the error term. Farmland values in levels could suffer from non-stationarity problems (Falk, 1991; Gutierrez et al., 2007), as a result, we examine stationarity with a Levin-Lin-Chu (2002) unit-root test for panel data and also test for co-integration using the bounds testing approach by Pesaran et al. (2001). Results indicate evidence of a long-run relationship between the variables, and based on these results, we employ the autoregressive distributed lag (ARDL) model. ${ }^{1}$ In our

\footnotetext{
${ }^{1}$ Results of the Levin-Lin-Chu unit-root test imply mixed variables in the model-farmland values are first-order stationary (i.e., integrated of order one or I(1)]; however, the regressors
} 
main specification, we use the ARDL $(1,1 ; 3)$ model where only one lag of $X_{i, t}$ and $Y_{i, t}$ are explicitly included. We provide a robustness check in Table IV column (3) for the ARDL $(2,2 ; 3)$ model with two lags included; however, we keep the one-lag model as the main model specification. We do this because the likelihood-ratio test statistics run with Stata, such as the final prediction error, Akaike's information criterion, Schwarz's Bayesian information criterion, and Hannan Quinn information criterion tests, suggest that the optimal lag length for interest rate - our variable of interest—is one lag. Additionally, the reported regressor signs correspond with those expected based on previous literature. In contrast, the two-lag model reports a negative and counterintuitive sign for both lagged farm income and lagged farmland value (the R-squared goodness-of-fit test rounds to $98 \%$ for both models, and thus no significant additional variation is explained by the two-lag model). The one-lag model is also maintained as the main specification model because it presents an opportunity to apply straightforward median lag length calculations deriving long-term impacts of interest rate changes, thus depicting the longrun effects of policy changes on farmland values without sacrificing additional observations.

We run the ARDL $(1,1 ; 3)$ model on the 1963-2018 timeline. The goodness-of-fit for the estimation sample, measured by the adjusted R-squared, estimates the accuracy of explained variation in land values. We investigate parameter stability by testing state-level cumulative sum

vary in the level of integration (stationary, i.e., integrated of order zero or $\mathrm{I}(0)$ or integrated of order one I(1) across the different regions). After the first condition of strict first-difference stationary, I(1) dependent variable was met (Sarkodie and Owusu, 2020; Jordan and Phillips, 2018; Shrestha and Bhatta, 2018), we test for co-integration using the bounds testing approach by Pesaran et al. (2001) — test variables appearing in lags of being jointly equal to zero. 
of recursive and OLS residuals. ${ }^{2}$ We fail to reject the null hypothesis of no structural break, thereby confirming the stability of the estimated parameters over time.

We calculate median lag lengths of the effects of real interest rate and inflation-adjusted gross farm income on farmland values using De Boef and Keele's (2008) methodology. We calculate median lag by quantifying individual effects at each lag, expressing them as proportions of the total effect of the long-run multiplier (LRM) variable, and identifying the lag when the sum of individual effects exceeds half of the cumulative effect. This calculation allows us to examine the speed and magnitude of the long-term impacts of changes in interest rates or farm income on farmland values.

Nickell (1981) shows possible bias in the coefficient of $Y_{i, t-1}$ in dynamic panel models with individual fixed effects (known as Nickell bias). A popular way to address this bias is to use the generalized method of moments approach proposed by Arellano and Bond (1991). In particular, we present a robustness check following the Arellano-Bond estimation methods using the second and third lags of land values as instrumental variables. We also run an additional robustness check using an error correction model (ECM), which ensures the data is stationary by considering differenced variables between years as dependent and independent variables, which we can derive from the ARDL specification (Bardsen, 1989; De Boef and Keele, 2008).

\section{Results and Discussion}

Table II presents the results of the main specification, the ARDL $(1,1 ; 3)$ model, for all Midwestern states combined, as well as for the I-states, Lakes states, and the Great Plains states

\footnotetext{
${ }^{2}$ CUSUM tests for parameter stability are not applicable to panel data; therefore, we have derived the test statistics with state-level regressions and used derived residuals as proxy for a CUSUM tests.
} 
separately. Consistent with the previous literature, our main results reveal a positive and significant relationship between land values and contemporaneous gross farm income (e.g., Featherstone et al., 2017; Reynolds and Timmons, 1969). For example, Table II column (2) shows that farmland values in the three I-states grow $1.55 \%$ with a $10 \%$ increase in contemporaneous gross farm income. In contrast, we find the lagged farm income to be not statistically significant in the model, which stems from the fact that farmland values quickly capitalize on changes in farm income, either induced by government payments or commodity price fluctuations, and our model suggests that this capitalization process is not a multi-year process. While the coefficient for contemporaneous interest rate expense is positive and significant, the coefficient for the lagged interest rate expense is negative and of a greater magnitude, leading to an overall negative correlation between interest rate expenses and farmland values.

[Insert Table II]

We also find current and previous interest rates are inversely related with farmland values, a finding that was previously reported (Burt, 1986; Nickerson and Zhang, 2014; Sherrick, 2018). The negative and significant coefficient on the lagged interest rates shown in Table II suggests that the effects of interest rate movements are long-lasting. Across all three regions, an F-test comparing the two coefficients for the federal funds rate show that the effect of the lagged real interest rates is much stronger than contemporaneous interest rate movements. Our results confirm the negative relationship between interest rates and farmland value. Our main model shows that a one-percentage-point increase in the federal funds rate would lead to a $0.8 \%$ immediate decline in the I-states land markets and a $0.5 \%$ decline in the Great Plains land 
markets. This result is comparable to that of Shaik et al. (2005), who find that a $10 \%$ increase in the real interest rate decreases farmland values by $2.5 \%$ (using data from 48 neighboring US states from 1940 to 2002). In addition, Reynolds and Timmons (1969) find that a 1\% increase in the capitalization rate on farmland value decreases farmland values with buildings (without buildings) by $0.73 \%$ to $1.45 \%$ ( $0.73 \%$ to $1.38 \%)$. More importantly, our results confirm findings of other studies that demonstrate the importance of lagged interest rates in explaining land values (e.g., Featherstone and Baker, 1987) and the ability of distributed lag and vector autoregression models in explaining variation in farmland prices (e.g., Burt, 1986; Falk, 1991; Just and Miranowski, 1993; Falk and Lee, 1998; Featherstone et al., 2017).

[Insert Table III]

Table III further shows that this relationship of lower interest rates leading to higher land values is stable under alternative measures of market interest rates, including 1-year or 10-year Constant Maturity Treasury (CMT-1 and CMT-10) rates and long-term farmland loan rates from the Federal Reserve Banks of Chicago and Kansas City. However, there are two differences when compared to our main results. First, the results using CMT-10 rates, as well as the Chicago and Kansas City Fed farmland loan rates, show that the coefficients for contemporaneous interest rates are similar to or larger than that for the lagged interest rates. This could result from the quicker and stronger responses of shorter-term market interest rates to changes in the federal funds rate target compared to intermediate- and long-term interest rates (Cook and Kahn, 1989). Despite that, our main findings, that the impact of interest rate changes are long-lasting, holds, 
with the peak of the effects realizing the year after the policy change (see Figure 2 ), ${ }^{3}$ and the capitalization path still exhibits a declining path spanning multiple years (see Figure A3). Second, the coefficients for the lagged Kansas City Fed interest rates are negative but not statistically significant, which may be due to its shorter time series that starts in 2001 - since then interest rates have seen less fluctuations compared to prior decades. As a result, we only use the other three market interest rates in constructing the capitalization path figures in Figure A3.

To more intuitively illustrate the long-run effects of interest rates, we follow De Boef and Keele (2008) and calculate the LRMs and the median lag length of its effects. In particular, the LRM measures the long-run cumulative effects distributed across many years induced by a onepercentage-point-change in interest rates, while the median lag length measures the number of years until the sum of individual effects exceeds half of the cumulative effect. The LRM analysis indicates that a one-percentage-point increase in the federal funds rate leads to a cumulative effect of $18 \%, 21 \%$, and $42 \%$ loss in farmland values in the I-states, Lakes states, and Great Plains states, respectively. However, it takes multiple years, at least a decade, for the full effects to capitalize in the farmland market.

[Insert Figure 2]

Figure 2a shows that the median lag length for the interest rate effect in the I-states was six years, which suggests that it takes at least a decade for farmland markets to capitalize the

\footnotetext{
${ }^{3}$ The larger coefficients for lagged CMT-10 and Chicago Fed farmland loan rates resulted in smaller gaps between the peak second-period effect and the contemporaneous first-period effect in Figure 2.
} 
entire effect of interest rate changes and that the interest rate effects peak in the year after the rate change and gradually become smaller in subsequent years. In particular, farmland values only capitalize $4.5 \%$ of the cumulative effect of an interest rate change in the same year, while the second and third years capture $13 \%$ and $11 \%$, respectively, of the long-run cumulative effect when examining the I-states farmland market movements. This temporal pattern with the strongest first lag contrasts with the pattern for the effects of the gross farm income for the Lakes states, where the immediate, contemporaneous shock comprises the largest effect as the percent of the total effect. Figure A1 in the appendix shows that the Lakes states and Great Plains states follow a similar pattern in median lag length calculations for interest rate effects- the peak is in the year immediately after the change occurs and is followed by a declining effect in successive years. In particular, it takes 12 and 18 years for the Lakes and Great Plains farmland markets, respectively, to capitalize half of the full effects of federal funds rate changes.

We demonstrate the stability of our key findings using five robustness checks in Table IV: $(a)$ an ARDL $(1,1 ; 3)$ model without time trend; $(b)$ an ARDL $(1,1 ; 2)$ model without time trend and interest expense for real estate; $(c)$ an ARDL $(2,2 ; 3)$ model with two lags of the dependent and independent variables; $(d)$ an Arellano-Bond approach to deal with the potential endogeneity in the lagged land value variable (Nickell bias); and, (e) an ECM specification that could be derived from the main ARDL model. Table A2 also present the ECM versions of the ARDL $(1,1 ; 3)$ model for all three Midwest regions presented in Table II. Table IV shows that our main findings of negative relationships between interest rates and farmland values remain consistent, so does the finding that lagged interest rates explain more variation in land values than contemporaneous interest rate measures. Figure A4 in the appendix, which uses an ARDL $(2,2 ; 3)$ model with two lags, shows a similar capitalization path declining over time, with the 
only difference being that the peak of the effect occurs two years, rather than one year, after the change in the federal funds rate. The Nickell bias addressed in column (5) presents an issue when quantifying the effects of lagged farmland values; however, our main focus is the interest rate.

\section{Policy Implications}

Our model results show that several of the factors that influence land values have sustained impacts lasting several years. The federal funds interest rate is one such factor. The federal funds rate is unique in that it is the only interest rate officially set by the Federal Reserve. Thus, it is the major policy lever used by the Federal Reserve to steer the economy. During the 2015-2018 calendar years, the Federal Reserve undertook a series of small interest rate hikes. To support the economy during the COVID-19 pandemic, the Federal Reserve has reversed course and reduced the federal funds rate twice to a near-zero level. However, our analysis shows that the 2019 reversal did not necessarily completely reverse the impacts of previous rate hikes. The timing and magnitude of the interest rate changes matter. To show this, we have isolated the projected changes in land values from the actual federal funds rate changes for the years 2015-2019 and the March 2020 interest rate cut, assuming the Federal Reserve does not make additional moves on the federal funds rate. Using the I-states and the federal funds rate, Figure 3 shows that the impacts on land values from interest rate changes carry on for several years after the initial change. ${ }^{4}$

\section{[Insert Figure 3]}

\footnotetext{
${ }^{4}$ Figure A2 in the appendix shows the overall patterns on the capitalization path of federal funds rate changes in land markets for the Lakes states and the Great Plains states are similar. Figure A3 further demonstrates the robustness of our main results by using alternative market interest rates such as US Treasury constant maturity rates and farm real estate loan rates.
} 
While the small hike in interest rates in 2015 had a minimal impact on land values, the sustained interest rate increases through 2016, 2017, and 2018 have had, and will have, a larger impact for farmland values. Isolating just the effects of interest rate changes alone, the Federal Reserve's moves contributed over a 1.5\% decline in farmland values for 2018, a 3.3\% decline for 2019 , and a projected $4 \%$ decline in 2020 . The interest rate reversal in 2019 will partially offset these effects, but the offset will take some time and will be relatively smaller. The larger cut in the interest rate in spring 2020 will fully offset the 2015-2018 hikes. Landowners felt the full weight of the 2015-2018 rate hikes in 2020 , which reduced farmland values by roughly $4 \%$. The peak impact from the 2019 interest rate cuts will come in 2021, pushing farmland values up by nearly $1.7 \%$. However, the combined force of the 2015-2018 interest rate hikes will still be roughly $4 \%$ at that same time, implying that the overall impact of the Federal Reserve's decisions has lowered farmland values by $0.8 \%$, despite the drastic 2020 rate cut. The peak impact from the 2020 cut will reveal itself in 2022, adding roughly $3.4 \%$ to land values, which will overwhelm the remaining impact from the 2015-2018 hikes. More importantly, the 2020 rate cut will dominate the interest rate impact for the foreseeable future, and the net effects of interest rate changes on farmland values will become positive, beginning in 2022. In particular, the farmland values in 2022,2023 , and 2024 will experience a net $1.6 \%, 1.4 \%$, and $1.2 \%$ increase, respectively, from the combined effect of all interest rate changes from 2015 to $2020 .^{5}$ These results indicate the long-lasting repercussions of the Federal Reserve's choices.

\footnotetext{
${ }^{5}$ Re-running the projections using the lowest values of the $95 \%$ parameter confidence interval for contemporaneous and lagged interest rates, our conclusion of the peak effect in the year after the policy change and the total effect becoming positive for farmland values in 2022 remain unchanged.
} 
Although we did not conduct a formal quantification of the unexpected components of the interest rate changes, ${ }^{6}$ we conjecture from historical dot plots from the Federal Open Market Committee meetings that the March 2020 cuts in federal funds rate contain a significant unexpected component, especially given its magnitude. As a result, our conclusion of a future land market dominated by supporting effects of lower interest rates is likely mostly driven by this surprise substantial cut in interest rates to combat the economic effects of the COVID-19 pandemic. Arguably, the initial interest rate hikes in late 2015 and the switch of federal monetary policy to cuts in 2019 are somewhat unexpected as well. In contrast, the 2018 interest rate hike, which is the largest in magnitude, and thus accountable for most of the effects of the hikes, was well telegraphed and expected.

Finally, we emphasize that the findings shown in Figure 3 are our projection, which assume no further changes in post-2020 interest rates, rather than a prediction of the future. Future changes in federal monetary policy could alter the future direction of the land market, and measurement errors could also arise for federal funds rate changes that are at the end of a year, as we attribute the policy year based on the date of the announcement.

\section{Summary and Conclusions}

\footnotetext{
${ }^{6}$ Previous studies on the impact of federal monetary policies on stock and asset prices have shown that most of the stock price reactions to changes in federal funds rate are due to the "surprise" or unexpected components (e.g., Bernanke and Kuttner, 2005; Gospodinov and Jamali, 2005), where the unexpected component is often measured as the difference between actual movements and the expected changes implied from the federal funds rate futures. In addition, the stock market tends to have a larger negative response to positive surprises, such as sudden interest rate hikes, and, in the case of interest rate cuts, the reaction is contingent on the magnitude of the cuts (Chuliá et al., 2010). More importantly, studies that separate the effects of the surprise components tend to rely on much more frequent data, at least at the monthly level, while our analysis relies on annual panel data series, which makes this quantification more challenging.
} 
Using three first-order autoregressive distributed lag models and a panel data of state-level farmland values from 1963 to 2018, we model the effects of recent interest rate changes on Midwestern farmland values and quantify the short-run and long-run effects by calculating the long-run multipliers and the median lag length of interest rate effects. Our key findings reveal that changes in the federal funds rate have long-lasting impacts on farmland values. In particular, the number of years necessary for half of the cumulative interest rate effect to dissipate is at least 6 years for the I-states, while it takes 12 and 18 years for the Lakes states and the Great Plains states, respectively. Consistent with the previous literature, our main results reveal a positive relationship with contemporaneous gross farm income, and current and previous interest rates are inversely related with farmland values.

Our model allows us to provide the first empirical quantification of the immediate and long-run impacts of recent Federal Reserve interest rate moves on farmland values. In particular, we find that the recent three federal funds rate cuts in 2019 were not sufficient to offset the downward pressures from the 2015-2018 interest rate hikes, but the 2020 cut will be. In fact, the cumulative effects of the interest rate cut in 2020 will dominate the impacts from the previous shifts, and farmland values in 2022 will experience a net $1.3 \%$ increase from all interest rate changes from 2015 to 2020 . These results highlight the importance and long-lasting impact of interest rate decisions on farmland values. The interest rate shifts in any given year have multiple reverberations for land values for several years afterward. The uptick in interest rates over the past few years has put downward pressure on farmland values. The recent reversal in interest rates has now offset that pressure.

Our models have several important underlying assumptions and thus have three limitations. First, we choose to place the Midwestern states into three particular groups (I-states, 
Lakes states, and the Great Plains states). Alternative groupings or individual state-level regressions may provide different results. Second, we focus on the long-run relationship between interest rate changes and farmland values and implicitly control for other factors outside of our study using the linear year trend. Issues may arise, as the trend may not adequately capture these other factors, such as disruptive events. Third, we use gross farm income at the state level to proxy for the income streams generated from the land. While all farm income is, in some way, derived from the land, some income streams, such as crops, more closely relate to the land than others, such as livestock. By using state-level farm income, we are commingling multiple income streams. Fourth, previous literature has shown that farmland with different land qualities may have heterogeneous trends and dynamics (e.g., Zhang et al., 2020), however, we cannot consider farmland heterogeneity within states because USDA only reports annual land value information at the state level. Fifth, future research could further distinguish the effects of federal funds rate changes due to expected or unexpected changes by following established literature in finance such as Kuttner (2001) and Bernanke and Kuttner (2005).

Farmland accounts for the vast majority of US farm assets, and a significant decline in farmland values could further exacerbate the brewing financial distress experienced by many producers. Researchers first estimated the 2015-2018 hikes would dominate the overall effects over the next few years, until the 2020 cut appeared. Now, the interest rate changes will support farmland values in the near future. Our analysis provides a useful framework to contextualize and quantify the farmland value impacts of Federal Reserve's choices on the federal funds rate. 


\section{References}

Arellano, M. and Bond, S. (1991), "Some tests of specification for panel data: Monte Carlo evidence and an application to employment equations. The Review of Economic Studies, Vol. 58 No. 2, pp. 277-297.

Bardsen, G. (1989), "Estimation of long run coefficients in error correction models." Oxford Bulletin of Economics and Statistics, Vol. 51 No. 3, pp. 345-350.

Bernanke, S.B. and Kuttner, N.K. (2005), "What explains the stock market's reaction to Federal Reserve policy?" The Journal of Finance, Vol. 60 No.3, pp. 1221-1257.

Burt, O. R. (1986), "Econometric modeling of the capitalization formula for farmland prices." American Journal of Agricultural Economics, Vol. 68 No. 1, pp. 10-26.

Chuliá, H., Martens, M. and van Dijk, D. (2010), "Asymmetric effects of federal funds target rate changes on S\&P100 stock returns, volatilities and correlations." Journal of Banking \& Finance, Vol. 34 No.4, pp. 834-839.

Cook, T. and Hahn, T. (1989), "The effect of changes in the federal funds rate target on market interest rates in the 1970s. Journal of Monetary Economics, Vol. 24 No. 3, pp. 331-351.

De Boef, S. and Keele, L. (2008), "Taking time seriously." American Journal of Political Science, Vol. 5 No. 1, pp. 184-200.

Falk, B. (1991), "Formally testing the present value model of farmland prices." American Journal of Agricultural Economics, Vol. 73 No. 1, pp. 1-10.

Falk, B. and Lee, B.-S. (1998), "Fads versus fundamentals in farmland prices." American Journal of Agricultural Economics, Vol. 80 No. 4, pp. 696-707.

Featherstone, A.M. and Baker, T.G. (1987), "An examination of farm sector real asset dynamics: 1910-85." American Journal of Agricultural Economics, Vol. 69 No. 3, pp. 532-546.

Featherstone, A.M., Taylor, M.R. and Gibson, H. (2017), "Forecasting Kansas land values using net farm income." Agricultural Finance Review, Vol. 77 No. 1, pp. 137-152.

Goodwin, B.K., Mishra, A.K. and Ortalo - Magné, F.N. (2003), "What's Wrong with Our Models of Agricultural Land Values?" Amercian Journal of Agricultural Economics, Vol. 85 No. 3., pp. 744.752. doi: 10.1111/1467-8276.00479.

Gospodinov, N. and Jamali, I. (2012), "The effects of Federal funds rate surprises on S\&P 500 volatility and volatility risk premium." Journal of Empirical Finance, Vol. 19 No.4, pp. 497-510.

Gutierrez, L., Westerlund, J. and Erickson, K. (2007), "Farmland prices, structural breaks and panel data." European Review of Agricultural Economics, Vol. 34 No. 2, pp. 161-179.

Jordan, S. and Philips, A.Q. (2018), "Cointegration testing and dynamic simulations of autoregressive distributed lag models." Stata Journal, Vol. 18 No. 4, pp. 902-923. 
Just, R.E. and Miranowski, J.A. (1993), "Understanding farmland price changes." American Journal of Agricultural Economics, Vol. 75 No. 1, pp. 156-168.

Kuttner, K N. (2001), "Monetary policy surprises and interest rates: evidence from the Fed funds futures market." Journal of Monetary Economics, Vol. 47 No. 3, pp. 523-544.

Lence, S. H. (2014), "Farmland prices: is this time different?" Applied Economic Perspectives and Policy, Vol. 36 No. 4, pp. 577-603.

Levin, A., C.-F. Lin, and C.-S. J. Chu, (2002). "Unit root tests in panel data: asymptotic and finite-sample properties." Journal of Econometrics, Vol. 108 No.1, pp. 1-24.

Melichar, E. (1979), "Capital gains versus current income in the farming sector." American Journal of Agricultural Economics, Vol. 61 No. 5, pp. 1085-1092. doi: 10.2307/3180381.

Moss, C.B. (1997), "Returns, interest rates, and inflation: how they explain changes in farmland values." American Journal of Agricultural Economics, Vol. 79 No. 4, pp. 1311-1318.

Nickell, S. (1981), "Biases in dynamic models with fixed effects." Econometrica, Vol. 49 No. 6, pp. 1417-1426.

Nickerson, C.J. and Zhang, W. (2014), "Modeling the determinants of farmland values in the United States," Oxford Handbook of Land Economics, Oxford University Press, Oxford, England, pp. 111-138.

Pesaran, M. H., Shin, Y. and Smith, R. J. (2001), "Bounds testing approaches to the analysis of level relationships." Journal of Applied Econometrics, Vol. 16 No. 3, pp. 289-326.

Reynolds, J.E. and Timmons, J.F. (1969). "Factors affecting farmland values in the United States." Iowa Agriculture and Home Economics Experiment Station Research Bulletin, Vol. 36 No. 566.

Romer, C.D. and Romer, D.H. (2000), "Federal reserve information and the behavior of interest rates." American Economic Review, Vol. 90 No. 3, pp. 429-457.

Sarkodie, S.A. and Owusu, P.A. (2020), "How to apply the novel dynamic ARDL simulations (dynardl) and Kernel-based regularized least squares (krls)." MethodsX, Vol. 7.

Shaik, S., Helmers, G.A. and Atwood, J.A. (2005), "The evolution of farm programs and their contribution to agricultural land values." American Journal of Agricultural Economics, Vol. 87 No. 5, pp. 119-1197.

Sherrick, B.J. (2018), "Understanding farmland values in a changing interest rate environment." Choices, Vol. 33 No. 1.

Shrestha, M.B. and Bhatta, G.R. (2018), "Selecting appropriate methodological framework for time series data analysis." The Journal of Finance and Data Science, Vol. 4 No. 2 , pp. 71-89.

Thornton, D.L. (1998), "Tests of the market's reaction to federal funds rate target changes." Federal Reserve Bank of St. Louis Review, Vol. 80 No. 6, pp. 25-36. 
U.S. Department of Agriculture Economic Research Service (USDA-ERS) (2020), "Highlights from the December 2020 Farm Income Forecast," available at:

https://www.ers.usda.gov/topics/farm-economy/farm-sector-income-finances/highlights-fromthe-farm-income-forecast/ (accessed 18 December 2020).

Weersink, A., Clark, S., Turvey, C. and Sarker, R. (1999), "The effect of agricultural policy on farmland values." Land Economics, Vol. 75 No. 3, pp. 425-439.

https://EconPapers.repec.org/RePEc:uwp:landec:v:75:y:1999:1:3:p:425-439.

Zhang, W. (2020), "2020 Iowa State University Land Value Survey: Overview.” CARD working paper 20-WP 613, Iowa State University Extension and Outreach, Center for Agricultural and Rural Development.

Zhang, W. and Nickerson, C.J. (2015) "The housing market bust and farmland values: identifying the changing influence of proximity to urban centers." Land Economics, Vol. 91 No. 4, pp. 605-626.

Zhang, W., S.H. Lence and T. Kuethe (2020), "Are expert opinions accurate? Panel data evidence from Iowa Land Value Survey." Accepted at Land Economics

Zhang, W. and Tidgren, K. (2018), "The current farm downturn vs the 1920s and 1980s farm crises: an economic and regulatory comparison." Agricultural Finance Review, Vol. 78 No. 4, pp. 396-411.

\section{Tables}

\section{Table I. Summary Statistics}

\begin{tabular}{llllll}
\hline Variable Description & Mean & Std. & Min & Max & Data Sources \\
& \multicolumn{3}{c}{ Dev. } \\
\hline State-level farmland values (\$/acre) & 2,557 & 1,662 & 483 & 8,986 & USDA-NASS June Area \\
Log of state-level farmland values & 7.63 & 0.683 & 6.18 & 9.10 & USDA-NASS June Area \\
(Landit) & & & & & Survey \\
Nominal federal funds rate (\%) & 5.17 & 3.63 & 0.09 & 16.38 & FRED Economic Data \\
Real federal funds rate (\%) & 1.28 & 2.29 & -3.32 & 6.13 & FRED Economic Data
\end{tabular}


State-level gross farm income

$(\$ 1,000 /$ acre $)$

Log of state-level gross farm

income (FarmIncit)

Interest expense for real estate

$(\$ 1,000 /$ acre $)$

Log of interest expense for real

estate

Real One-Year Treasury Constant
5,827

7,496

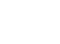

Statistics

$15.54 \quad 0.79$

13.49

17.40

USDA-ERS Farm

Income and Wealth

Statistics

$419 \quad 258$

79

185

USDA-ERS Farm

Income and Wealth

Statistics

12.79

0.56

11.27

14.43

USDA-ERS Farm

Income and Wealth

Statistics

Maturity Rate (CMT-1)

Real 10-Year Treasury Constant

2.34

2.28

$-3.49$

8.16

6.61

FRED Economic Data

Maturity Rate (CMT-10)

Real Chicago Federal Reserve Bank 4.63

Farmland Loan Rate

Real Kansas City Federal Reserve

4.45

1.06

Bank Long-Term Real Estate Rates

Inflation Rate (\%)

10.1

Chicago Fed Ag

Conditions

Kansas City Fed Ag

Finance Databook

$\begin{array}{lll}0.28 & -0.04 & 13.55\end{array}$

FRED Economic Data 
Table II. Impacts of Interest Rate Changes on Farmland Values 1963-2018 based on ARDL $(1,1 ; 3)$ Model

\begin{tabular}{|c|c|c|c|c|}
\hline & $\begin{array}{l}\text { All Midwest } \\
\text { states }\end{array}$ & I-states & Lakes states & Great Plains \\
\hline \multirow[t]{2}{*}{$\operatorname{Land}_{(\mathrm{t}-1)}$} & $0.930^{* * *}$ & $0.866^{* * *}$ & $0.937 * * *$ & $0.959^{* * *}$ \\
\hline & $(0.015)$ & $(0.007)$ & $(0.013)$ & $(0.020)$ \\
\hline \multirow[t]{2}{*}{ Real Fed Funds Rate $(\mathrm{t})$} & $-0.499 * * *$ & -0.797 & -0.086 & $-0.523^{* *}$ \\
\hline & $(0.145)$ & $(0.287)$ & $(0.360)$ & $(0.134)$ \\
\hline \multirow[t]{2}{*}{ Real Fed Funds Rate(t-1) } & $-1.306^{* * *}$ & $-1.572 * * *$ & $-1.263 * * *$ & $-1.191 * * *$ \\
\hline & $(0.092)$ & $(0.158)$ & $(0.130)$ & $(0.111)$ \\
\hline \multirow[t]{2}{*}{ Farm Income (t) } & $0.123 * * *$ & $0.155^{* *}$ & $0.169 * * *$ & $0.110^{* *}$ \\
\hline & $(0.015)$ & $(0.022)$ & $(0.013)$ & $(0.028)$ \\
\hline \multirow[t]{2}{*}{ Farm Income $_{(\mathrm{t}-1)}$} & 0.013 & 0.033 & -0.077 & 0.065 \\
\hline & $(0.027)$ & $(0.023)$ & $(0.080)$ & $(0.038)$ \\
\hline \multirow[t]{2}{*}{ Interest Expense } & $0.142 * * *$ & $0.243 * *$ & $0.119 *$ & $0.114^{*}$ \\
\hline & $(0.032)$ & $(0.027)$ & $(0.049)$ & $(0.052)$ \\
\hline \multirow[t]{2}{*}{ Interest Expense(t-1) } & $-0.206 * * *$ & $-0.297 * *$ & $-0.181^{*}$ & $-0.200 * * *$ \\
\hline & $(0.026)$ & $(0.031)$ & $(0.057)$ & $(0.032)$ \\
\hline \multirow[t]{2}{*}{ Constant } & $8.746^{* * *}$ & 2.409 & 2.055 & $7.431 * *$ \\
\hline & (1.609) & $(1.459)$ & $(1.889)$ & (2.118) \\
\hline Obs. & 672 & 168 & 224 & 280 \\
\hline Adjusted R-squared & 0.976 & 0.975 & 0.980 & 0.975 \\
\hline Linear Trend & Yes & Yes & Yes & Yes \\
\hline
\end{tabular}


$\begin{array}{lllll}\text { State Fixed Effects } & \text { Yes } & \text { Yes } & \text { Yes } & \text { Yes }\end{array}$

Note: Dependent variable for all regressions is Land(t). Robust standard errors are in parenthesis. $* * * \mathrm{p}<0.01, * * \mathrm{p}<0.05, * \mathrm{p}<0.10$ 
Table III. Robustness Checks for I-states using Alternative Measures of Interest Rates other than Inflation-adjusted Federal Funds Rates

\begin{tabular}{|c|c|c|c|c|}
\hline & & & & Real Kansas \\
\hline & $\begin{array}{c}\text { Real CMT-1 } \\
\text { rates }\end{array}$ & $\begin{array}{c}\text { Real CMT-10 } \\
\text { rates }\end{array}$ & $\begin{array}{c}\text { Real Chicago } \\
\text { Fed farmland } \\
\text { loan rates }\end{array}$ & $\begin{array}{l}\text { City Fed long- } \\
\text { term real } \\
\text { estate loan } \\
\text { rates }\end{array}$ \\
\hline $\operatorname{Land}_{(\mathrm{t}-1)}$ & $\begin{array}{c}0.868 * * * \\
(0.007)\end{array}$ & $\begin{array}{c}0.871 * * * \\
(0.006)\end{array}$ & $\begin{array}{c}0.859 * * * \\
(0.008)\end{array}$ & $\begin{array}{c}0.787 * * * \\
(0.038)\end{array}$ \\
\hline 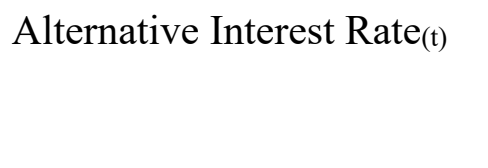 & $\begin{array}{l}-0.894 * \\
(0.273)\end{array}$ & $\begin{array}{c}-1.158 * * \\
(0.132)\end{array}$ & $\begin{array}{c}-1.215^{* * *} \\
(0.114)\end{array}$ & $\begin{array}{c}-2.539 * * \\
(0.341)\end{array}$ \\
\hline Alternative Interest Rate $(\mathrm{t}-1)$ & $\begin{array}{c}-1.332 * * \\
(0.148)\end{array}$ & $\begin{array}{c}-0.855^{* *} \\
(0.189)\end{array}$ & $\begin{array}{c}-0.973 * * * \\
(0.088)\end{array}$ & $\begin{array}{l}-0.021 \\
(0.483)\end{array}$ \\
\hline $\operatorname{Farm~Income~}_{(t)}$ & $\begin{array}{l}0.152 * * \\
(0.023)\end{array}$ & $\begin{array}{l}0.167 * * \\
(0.027)\end{array}$ & $\begin{array}{l}0.154 * \\
(0.036)\end{array}$ & $\begin{array}{c}0.180 \\
(0.067)\end{array}$ \\
\hline Farm Income $(\mathrm{t}-1)$ & $\begin{array}{c}0.030 \\
(0.018)\end{array}$ & $\begin{array}{l}0.044 * \\
(0.011)\end{array}$ & $\begin{array}{c}0.037 \\
(0.019)\end{array}$ & $\begin{array}{l}0.149 * * \\
(0.033)\end{array}$ \\
\hline Interest Expense & $\begin{array}{c}0.240 * * * \\
(0.023)\end{array}$ & $\begin{array}{c}0.157 * * * \\
(0.001)\end{array}$ & $\begin{array}{l}0.174 * * \\
(0.027)\end{array}$ & $\begin{array}{l}-0.005 \\
(0.033)\end{array}$ \\
\hline Interest Expense $(\mathrm{t}-1)$ & $\begin{array}{c}-0.303 * * * \\
(0.024)\end{array}$ & $\begin{array}{c}-0.240 * * * \\
(0.002)\end{array}$ & $\begin{array}{c}-0.224 * * \\
(0.030)\end{array}$ & $\begin{array}{c}0.028 \\
(0.065)\end{array}$ \\
\hline Constant & $\begin{array}{l}9.341 * * \\
(1.667)\end{array}$ & $\begin{array}{c}10.034 * * \\
(1.490)\end{array}$ & $\begin{array}{l}6.765 * * \\
(1.486)\end{array}$ & $\begin{array}{l}16.159 * \\
(3.824)\end{array}$ \\
\hline
\end{tabular}


Obs

168

168

144

51

Adjusted R-squared

0.974

0.973

0.972

0.983

Linear Year Trend

Yes

Yes

Yes

Yes

State Fixed Effects

Yes

Yes

Yes

Yes

Note: The dependent variable for all regressions is Land $(\mathrm{t})$. Robust standard errors are in parenthesis. Chicago Fed farmland loan rates started in 1970. Kansas City Fed Agricultural Finance Databook Long Term Real Estate Loan Rates started in $2001 .{ }^{* * *} \mathrm{p}<0.01, * * \mathrm{p}<0.05, *$ $\mathrm{p}<0.10$. 
Table IV. Robustness Checks using ARDL $(1,1 ; 3)$ without Time Trend, ARDL $(1,1 ; 2)$ without Time Trend and Interest

Expense, ARDL $(2,2 ; 3)$ Model with Two Lags, an Arellano Bond Model, and an Error Correction Model for I-States

\begin{tabular}{|c|c|c|c|c|c|}
\hline Model & $\begin{array}{l}\text { ARDL without time } \\
\text { trend }\end{array}$ & $\begin{array}{l}\text { ARDL without time } \\
\text { trend and interest } \\
\text { expense }\end{array}$ & $\begin{array}{l}\text { ARDL with two lags of } \\
\text { the dependent and } \\
\text { independent variables }\end{array}$ & Arellano-Bond & ECM \\
\hline Dependent Variable & $\operatorname{Land}_{(\mathrm{t})}$ & $\operatorname{Land}_{(\mathrm{t})}$ & $\operatorname{Land}_{(t)}$ & $\operatorname{Land}_{(t)}$ & $\Delta \operatorname{Land}_{(\mathrm{t})}$ \\
\hline $\operatorname{Land}_{(\mathrm{t}-1)}$ & $\begin{array}{c}0.877 * * * \\
(0.001)\end{array}$ & $\begin{array}{c}0.913 * * * \\
(0.002)\end{array}$ & $\begin{array}{c}1.086^{* * *} \\
(0.049)\end{array}$ & $\begin{array}{c}0.906 * * * \\
(0.016)\end{array}$ & $\begin{array}{c}-0.134 * * * \\
(0.007)\end{array}$ \\
\hline $\operatorname{Land}_{(\mathrm{t}-2)}$ & & & $\begin{array}{c}-0.256 * * \\
(0.046)\end{array}$ & & \\
\hline Interest Rate $(\mathrm{t})$ & $\begin{array}{l}-0.927 * \\
(0.295)\end{array}$ & $\begin{array}{l}-0.842 * \\
(0.219)\end{array}$ & $\begin{array}{l}-0.885^{*} \\
(0.277)\end{array}$ & $\begin{array}{c}-0.791 * * * \\
(0.305)\end{array}$ & \\
\hline Interest Rate(t-1) & $\begin{array}{c}-1.823 * * * \\
(0.127)\end{array}$ & $\begin{array}{c}-2.190 * * * \\
(0.107)\end{array}$ & $\begin{array}{l}-0.705^{*} \\
(0.212)\end{array}$ & $\begin{array}{c}-1.679 * * * \\
(0.322)\end{array}$ & $\begin{array}{c}-2.368 * * * \\
(0.213)\end{array}$ \\
\hline Interest Rate $(\mathrm{t}-2)$ & & & $\begin{array}{l}-1.018 \\
(0.416)\end{array}$ & & \\
\hline
\end{tabular}




\begin{tabular}{|c|c|c|c|c|c|}
\hline \multirow[t]{2}{*}{ Farm Income $_{(\mathrm{t})}$} & $0.081 * *$ & $0.084 * *$ & $0.114 * *$ & $0.099 * * *$ & \\
\hline & $(0.012)$ & $(0.013)$ & $(0.015)$ & $(0.037)$ & \\
\hline \multirow[t]{2}{*}{ Farm Income $(\mathrm{t}-1)$} & $-0.047 *$ & $-0.078 * *$ & -0.022 & -0.051 & $0.188^{* *}$ \\
\hline & $(0.012)$ & $(0.011)$ & $(0.014)$ & $(0.036)$ & $(0.037)$ \\
\hline \multirow[t]{2}{*}{ Farm Income $_{(\mathrm{t}-2)}$} & & & $0.083 * *$ & & \\
\hline & & & $(0.016)$ & & \\
\hline \multirow[t]{2}{*}{ Interest Expense } & $0.281 * *$ & & $0.094 * *$ & $0.204 * * *$ & $-0.055 * * *$ \\
\hline & $(0.034)$ & & $(0.010)$ & $(0.059)$ & $(0.004)$ \\
\hline \multirow[t]{2}{*}{ Interest Expense $(\mathrm{t}-1)$} & $-0.279 * * *$ & & 0.039 & $-0.237 * * *$ & \\
\hline & $(0.028)$ & & $(0.021)$ & $(0.054)$ & \\
\hline \multirow[t]{2}{*}{ Interest Expense $(\mathrm{t}-2)$} & & & $-0.165 * *$ & & \\
\hline & & & $(0.026)$ & & \\
\hline \multirow[t]{2}{*}{$\Delta$ Interest Rate } & & & & & -0.797 \\
\hline & & & & & $(0.287)$ \\
\hline$\Delta$ Farm Income & & & & & $0.155 * *$ \\
\hline
\end{tabular}


$\Delta$ Interest Expense

Constant

0.493*

(0.123)

Obs.

Linear Year Trend

State Fixed Effects
168

0.973

Yes
$0.687 * * *$

(0.046)

168

0.970

Yes

Yes
$8.946^{* * *}$

(0.816)

165

0.981

Yes

Yes
$0.243^{* *}$

(0.027)

2.505

(1.663)

168

N/A

Yes

Yes
0.545

$9.929 * *$

68

Yes

Yes

Robust standard errors are in parenthesis. ${ }^{* * *} \mathrm{p}<0.01,{ }^{* *} \mathrm{p}<0.05, * \mathrm{p}<0.10$. 


\section{Figures}

Figure 1. Nominal interest rates used in the main ARDL $(1,1 ; 3)$ model, 1963-2020

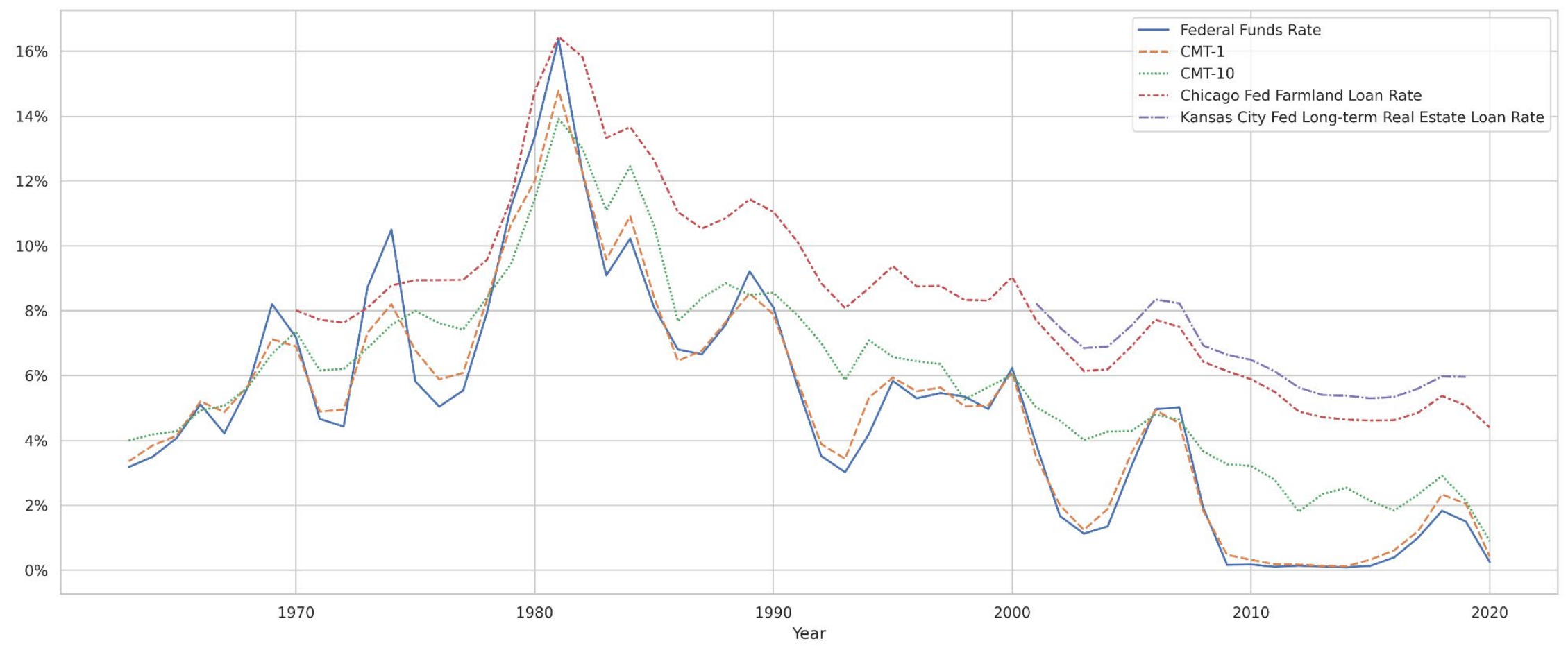

Note: Chicago Fed farmland loan rates started in 1970. Kansas City Fed Agricultural Finance Databook Long Term Real Estate Loan

Rates started in 2001 and was discontinued in 2020. 
Figure 2. Median lag length of interest rate impacts for I-States: (a) federal funds rate; and, (b) Chicago Fed farmland loan rate

Figure 2a. Median lag length of interest rate impacts for I-States (Federal funds rate).

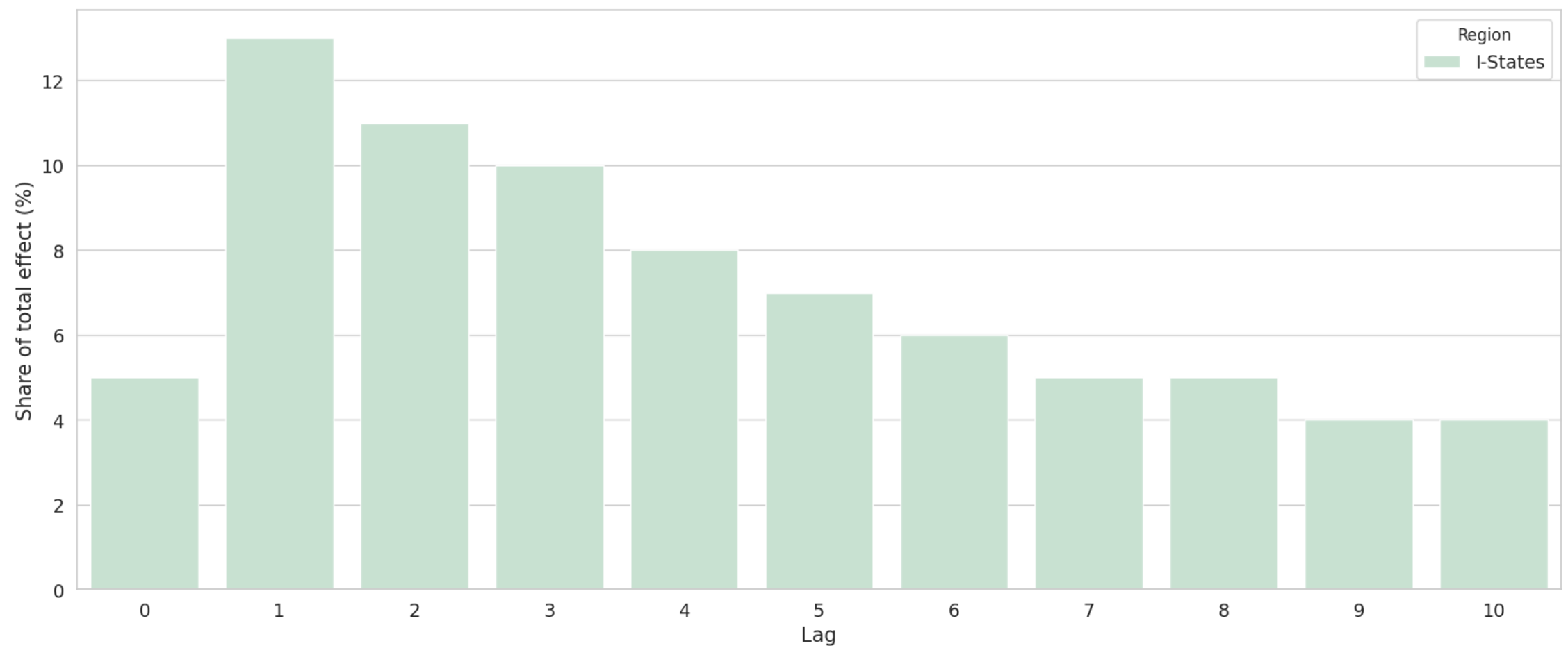


Figure 2b. Median lag length of interest rate impacts for I-States (Chicago Fed farmland loan rate).

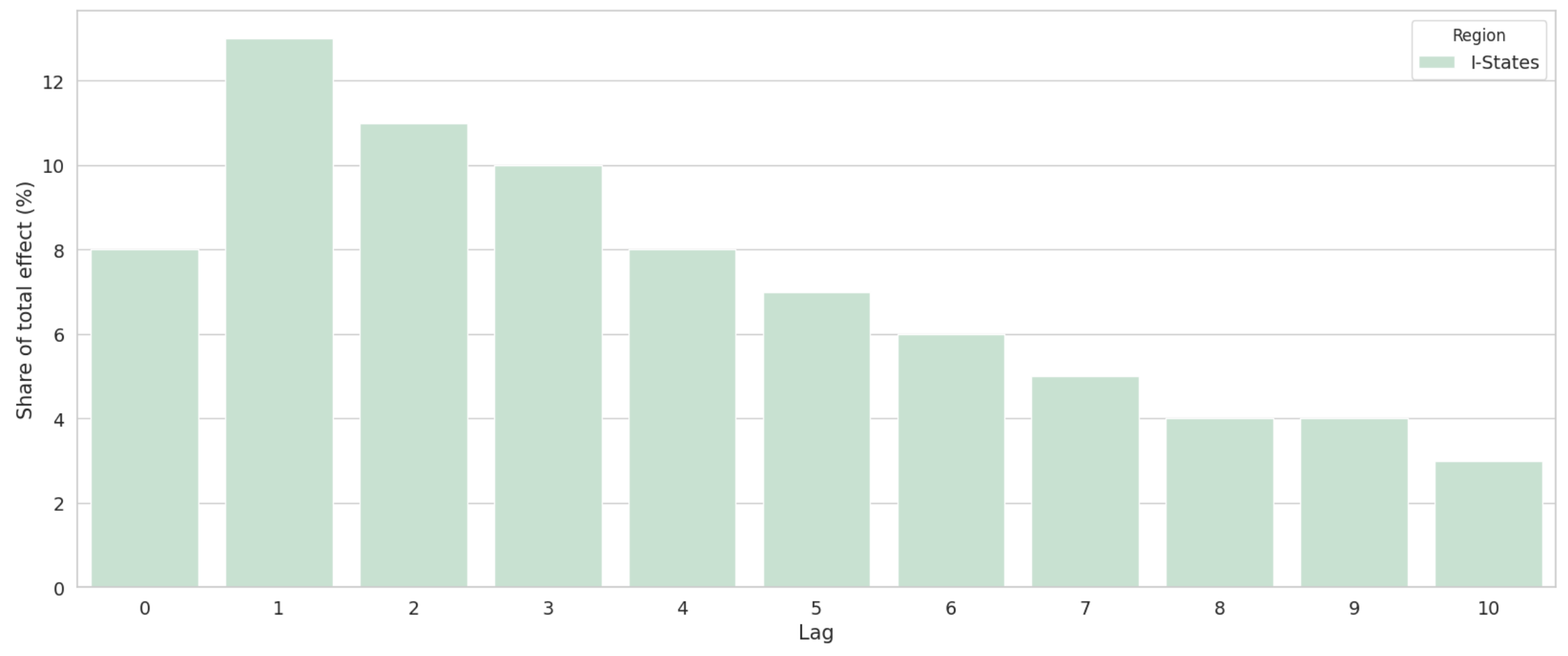


Figure 3. The short- and long-term impacts of recent Federal Reserve interest rate moves on I-states' farmland values.

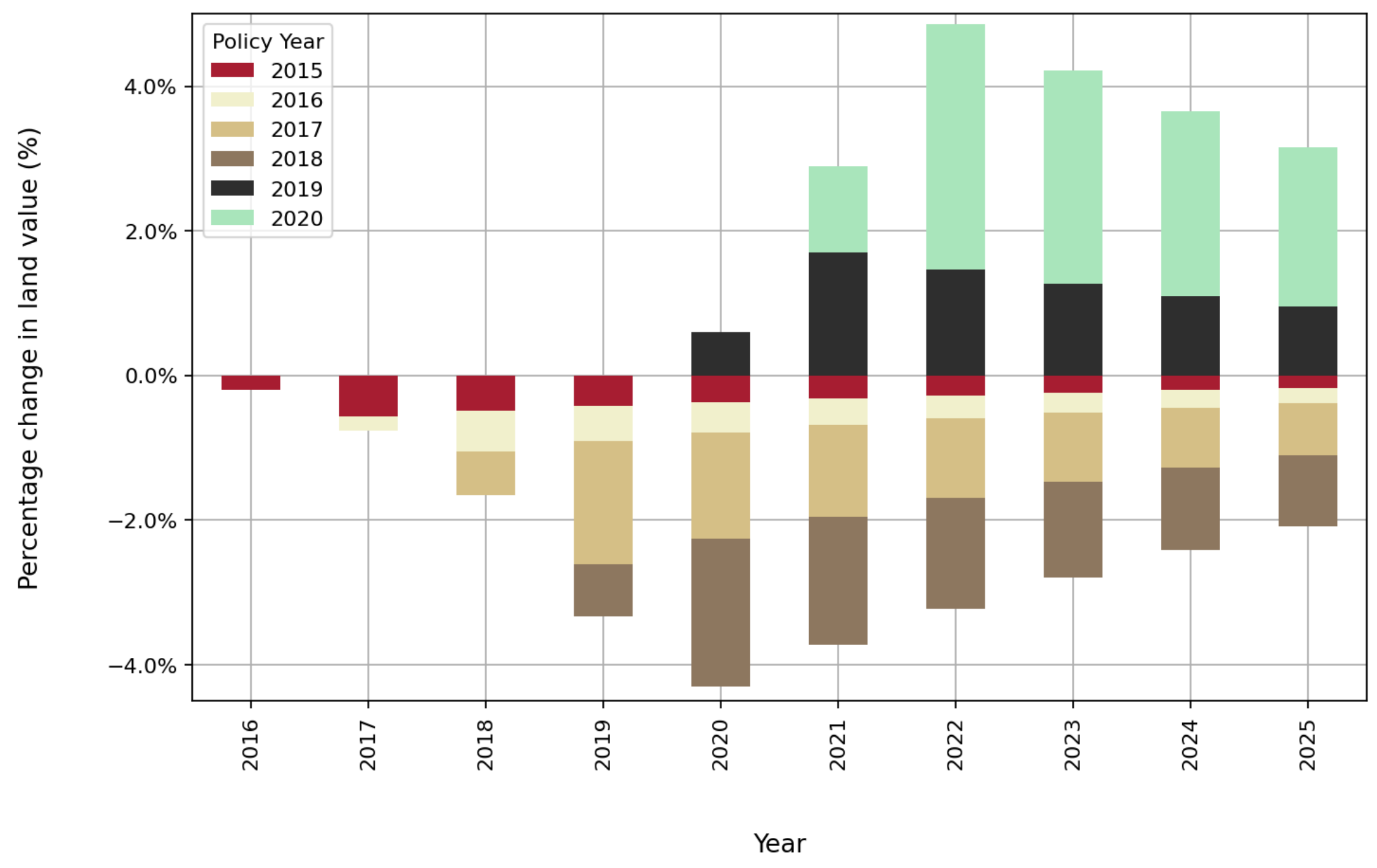




\section{Appendix}

Table A1. Robustness Checks for Lakes and Great Plains States using Alternative Measures of Interest Rates other than Inflation-adjusted Federal Funds Rate

\begin{tabular}{|c|c|c|c|c|}
\hline & \multicolumn{2}{|c|}{ Lakes States } & \multicolumn{2}{|c|}{ Great Plains States } \\
\hline & $\begin{array}{c}\text { Real } \\
\text { Chicago Fed } \\
\text { farmland } \\
\text { loan rates }\end{array}$ & $\begin{array}{c}\text { Real Kansas } \\
\text { City Fed long- } \\
\text { term real } \\
\text { estate loan } \\
\text { rates }\end{array}$ & $\begin{array}{l}\text { Real Chicago } \\
\text { Fed farmland } \\
\text { loan rates }\end{array}$ & $\begin{array}{c}\text { Real Kansas } \\
\text { City Fed long- } \\
\text { term real } \\
\text { estate loan } \\
\text { rates }\end{array}$ \\
\hline $\operatorname{Land}_{(\mathrm{t}-1)}$ & $\begin{array}{c}0.935 * * * \\
(0.012)\end{array}$ & $\begin{array}{c}0.925 * * * \\
(0.098)\end{array}$ & $\begin{array}{c}0.928 * * * \\
(0.016)\end{array}$ & $\begin{array}{c}0.814 * * * \\
(0.039)\end{array}$ \\
\hline Alternative Interest Rate(t) & $\begin{array}{l}-0.592 \\
(0.322)\end{array}$ & $\begin{array}{l}-1.263 \\
(0.711)\end{array}$ & $\begin{array}{c}-0.898 * * * \\
(0.179)\end{array}$ & $\begin{array}{c}-2.193 * * * \\
(0.307)\end{array}$ \\
\hline Alternative Interest Rate $(t-1)$ & $\begin{array}{l}-0.805 \\
(0.401)\end{array}$ & $\begin{array}{c}-1.035 * \\
(0.431)\end{array}$ & $\begin{array}{c}-1.116^{* *} \\
(0.335)\end{array}$ & $\begin{array}{l}-0.904 \\
(0.589)\end{array}$ \\
\hline Farm Income $_{(\mathrm{t})}$ & $\begin{array}{l}0.138 * * \\
(0.028)\end{array}$ & $\begin{array}{c}0.115 \\
(0.077)\end{array}$ & $\begin{array}{c}0.127 * * \\
(0.040)\end{array}$ & $\begin{array}{c}0.179 * * \\
(0.043)\end{array}$ \\
\hline Farm Income(t-1) & $\begin{array}{l}-0.063 \\
(0.064)\end{array}$ & $\begin{array}{c}0.040 \\
(0.082)\end{array}$ & $\begin{array}{c}0.060 \\
(0.048)\end{array}$ & $\begin{array}{c}0.225 * * * \\
(0.027)\end{array}$ \\
\hline Interest Expense & $\begin{array}{l}0.089 * \\
(0.038)\end{array}$ & $\begin{array}{l}-0.002 \\
(0.053)\end{array}$ & $\begin{array}{c}0.059 \\
(0.055)\end{array}$ & $\begin{array}{l}-0.086 \\
(0.045)\end{array}$ \\
\hline Interest Expense(t-1) & $\begin{array}{c}-0.162 * * \\
(0.043)\end{array}$ & $\begin{array}{c}0.046 \\
(0.077)\end{array}$ & $\begin{array}{l}-0.113 * \\
(0.041)\end{array}$ & $\begin{array}{c}0.117 * * * \\
(0.024)\end{array}$ \\
\hline Constant & 3.532 & 19.437 & $9.794^{*}$ & $21.408 * * *$ \\
\hline
\end{tabular}


Obs.

192

68

240

85

Adjusted R-squared

0.976

0.965

0.974

0.981

Linear Year Trend

Yes

Yes

Yes

Yes

State Fixed Effects

Yes

Yes

Yes

Yes

Note: Dependent variable for all regressions is Land $(\mathrm{t})$. Robust standard errors are in parenthesis.

Chicago Fed farmland loan rates started in 1970. Kansas City Fed Agricultural Finance

Databook Long Term Real Estate Loan Rates started in 2001. ${ }^{* * *} \mathrm{p}<0.01,{ }^{* *} \mathrm{p}<0.05,{ }^{*} \mathrm{p}<0.10$. 
Table A2. Error Correction Versions of the ARDL $(1,1,3)$ Model for I-states, Lake States, Great Plains States, and Combined Midwest States

\begin{tabular}{|c|c|c|c|c|}
\hline & $\begin{array}{l}\text { All Midwest } \\
\text { states }\end{array}$ & I-states & Lakes states & Great Plains \\
\hline \multirow[t]{2}{*}{$\operatorname{Land}_{(\mathrm{t}-1)}$} & $-0.070 * * *$ & $-0.134 * * *$ & $-0.063 * *$ & -0.041 \\
\hline & $(0.015)$ & $(0.007)$ & $(0.013)$ & $(0.020)$ \\
\hline \multirow[t]{2}{*}{$\Delta$ Real Fed Funds Rate $(\mathrm{t})$} & $-0.499 * * *$ & -0.797 & -0.086 & $-0.523 * *$ \\
\hline & $(0.145)$ & $(0.287)$ & $(0.360)$ & $(0.134)$ \\
\hline \multirow[t]{2}{*}{ Real Fed Funds Rate $(\mathrm{t}-1)$} & $-1.805 * * *$ & $-2.368 * * *$ & $-1.349 * *$ & $-1.715 * * *$ \\
\hline & $(0.188)$ & $(0.213)$ & $(0.357)$ & $(0.240)$ \\
\hline \multirow[t]{2}{*}{$\Delta$ Farm Income $_{(\mathrm{t})}$} & $0.123 * * *$ & $0.155^{* *}$ & $0.169 * * *$ & $0.110 * *$ \\
\hline & $(0.015)$ & $(0.022)$ & $(0.013)$ & $(0.028)$ \\
\hline \multirow[t]{2}{*}{ Farm Income $_{(\mathrm{t}-1)}$} & $0.137 * * *$ & $0.188 * *$ & 0.092 & $0.175 * *$ \\
\hline & $(0.021)$ & $(0.037)$ & $(0.068)$ & $(0.039)$ \\
\hline \multirow[t]{2}{*}{$\Delta$ Interest Expense } & $0.142 * * *$ & $0.243 * *$ & $0.119 *$ & $0.114 *$ \\
\hline & $(0.032)$ & $(0.027)$ & $(0.049)$ & $(0.052)$ \\
\hline \multirow[t]{2}{*}{ Interest Expense $(\mathrm{t}-1)$} & $-0.064 * * *$ & $-0.055 * * *$ & $-0.061 * *$ & $-0.086^{* *}$ \\
\hline & $(0.009)$ & $(0.004)$ & $(0.017)$ & $(0.020)$ \\
\hline \multirow[t]{2}{*}{ Constant } & $8.746 * * *$ & $9.929 * *$ & 5.373 & $12.681 * *$ \\
\hline & $(1.609)$ & $(2.175)$ & $(4.571)$ & $(3.373)$ \\
\hline Obs. & 672 & 168 & 224 & 280 \\
\hline Adjusted R-squared & 0.465 & 0.567 & 0.437 & 0.470 \\
\hline Linear Trend & Yes & Yes & Yes & Yes \\
\hline
\end{tabular}


$\begin{array}{lllll}\text { State Fixed Effects } & \text { Yes } & \text { Yes } & \text { Yes } & \text { Yes }\end{array}$

Note: Dependent variable for all regressions is $\Delta \operatorname{Land}_{(\mathrm{t})}$. Robust standard errors are in parenthesis. $* * * \mathrm{p}<0.01, * * \mathrm{p}<0.05, * \mathrm{p}<0.10$. 
Figure A1. Median lag length using real federal funds rates for the Great Plains and Lakes states

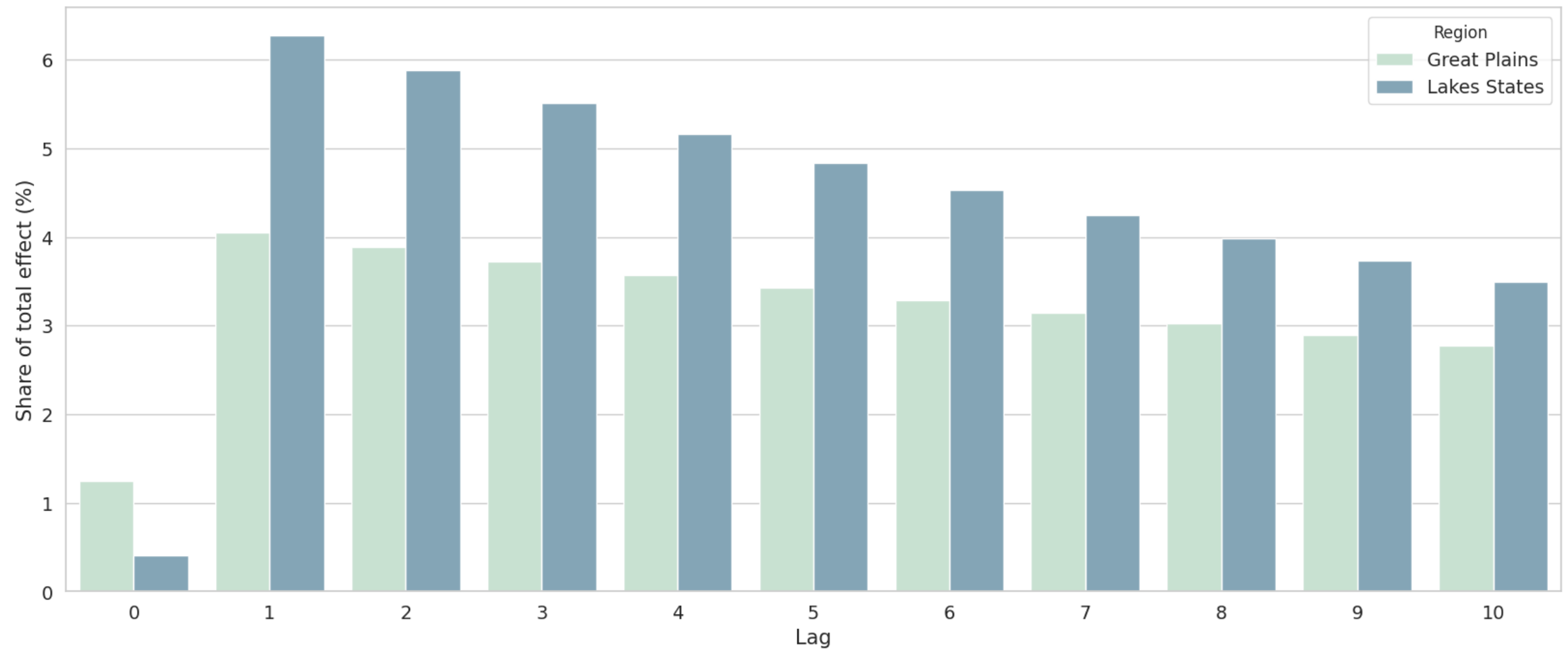


Figure A2. The short- and long-term impacts of recent Federal Reserve interest rate moves on (A) Lake's and (B) Great Plains' farmland values.

(A: Lakes states)

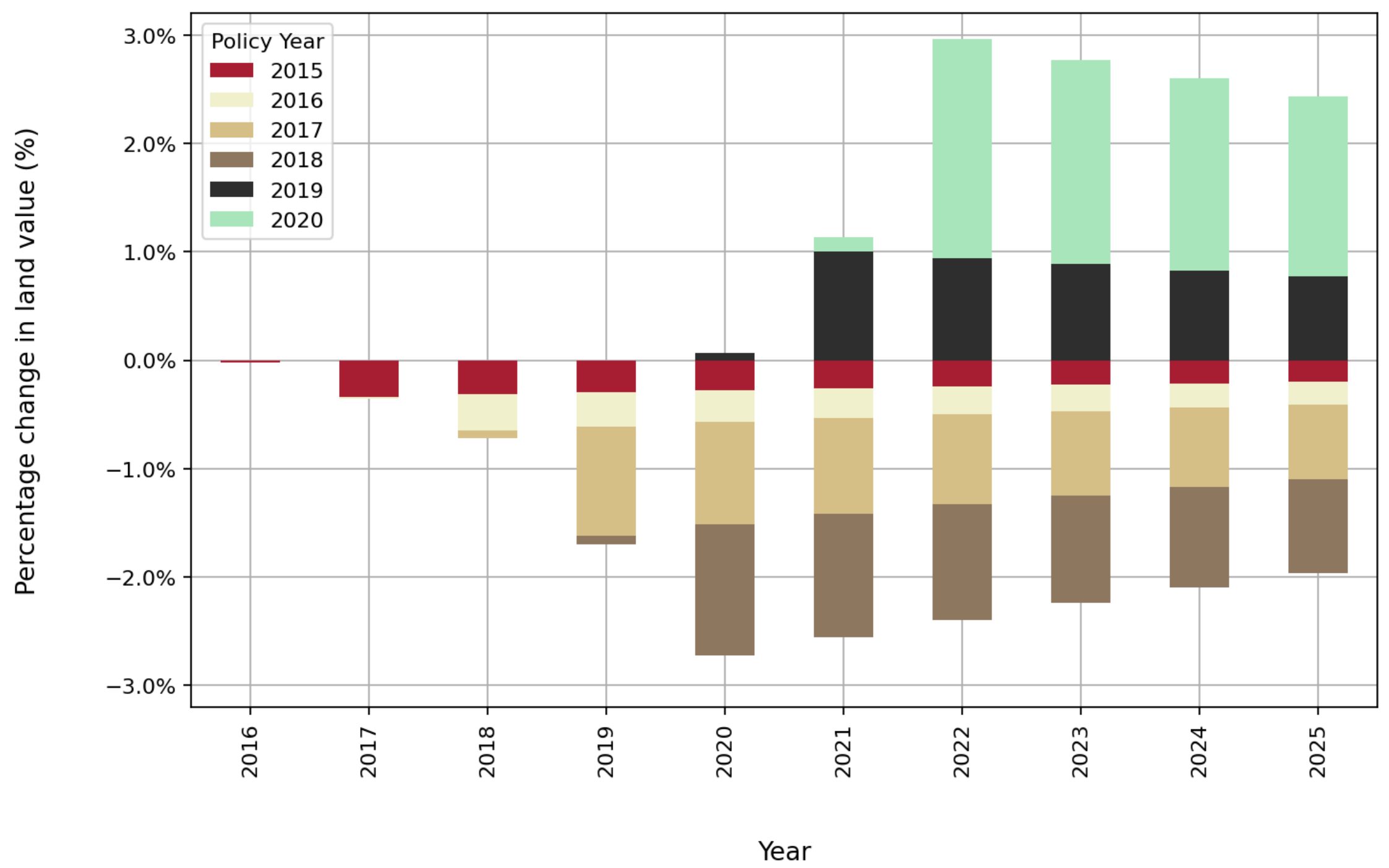


(B: Great Plains States)

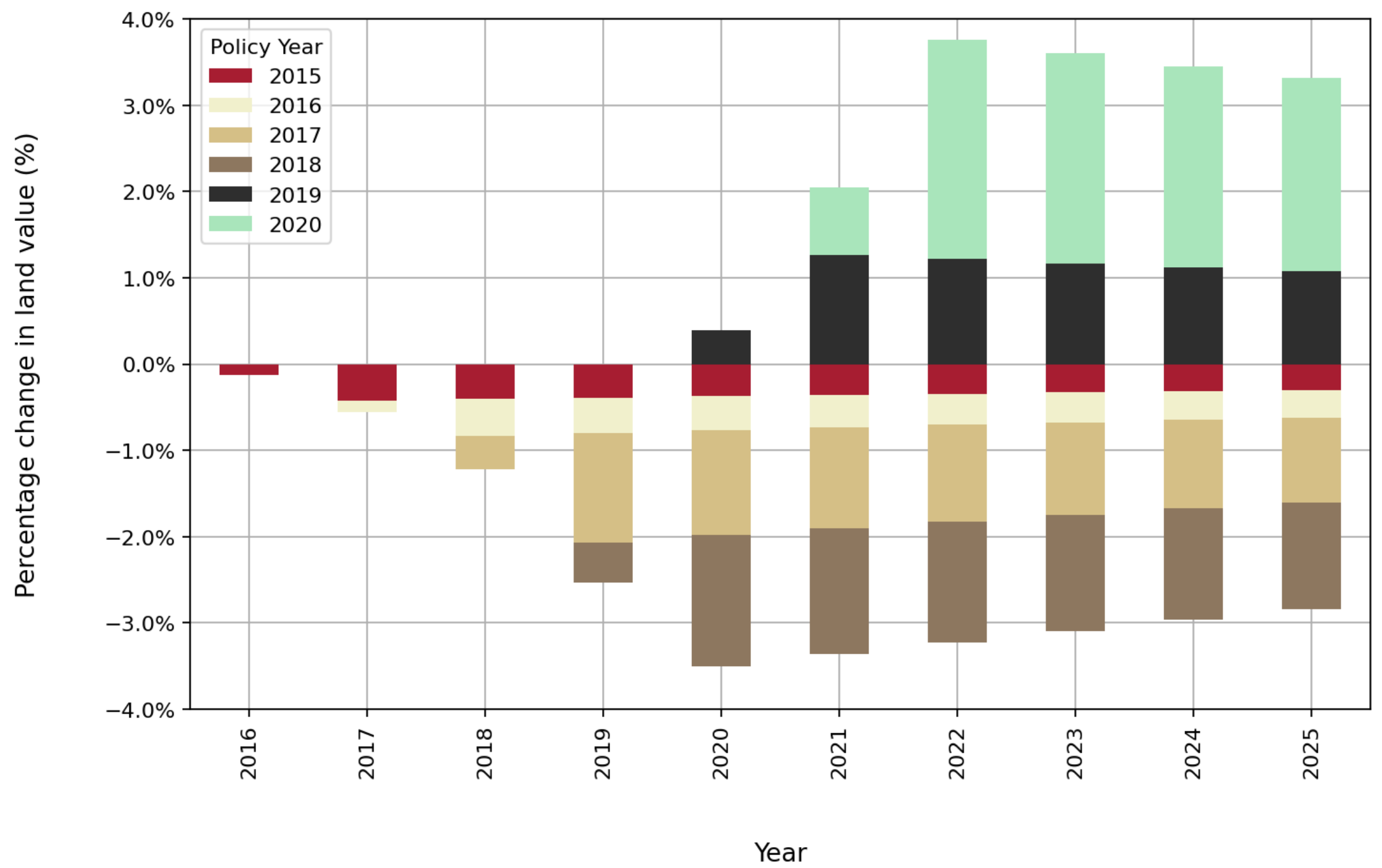


Figure A3. The short- and long-term impacts of interest rate moves on (A) Kansas City Fed loan rates, (B) Chicago Fed loan rates, (C) CMT-10, and (D) CMT-1 on I-states' farmland values.

(A: Kansas City Fed loan rates)

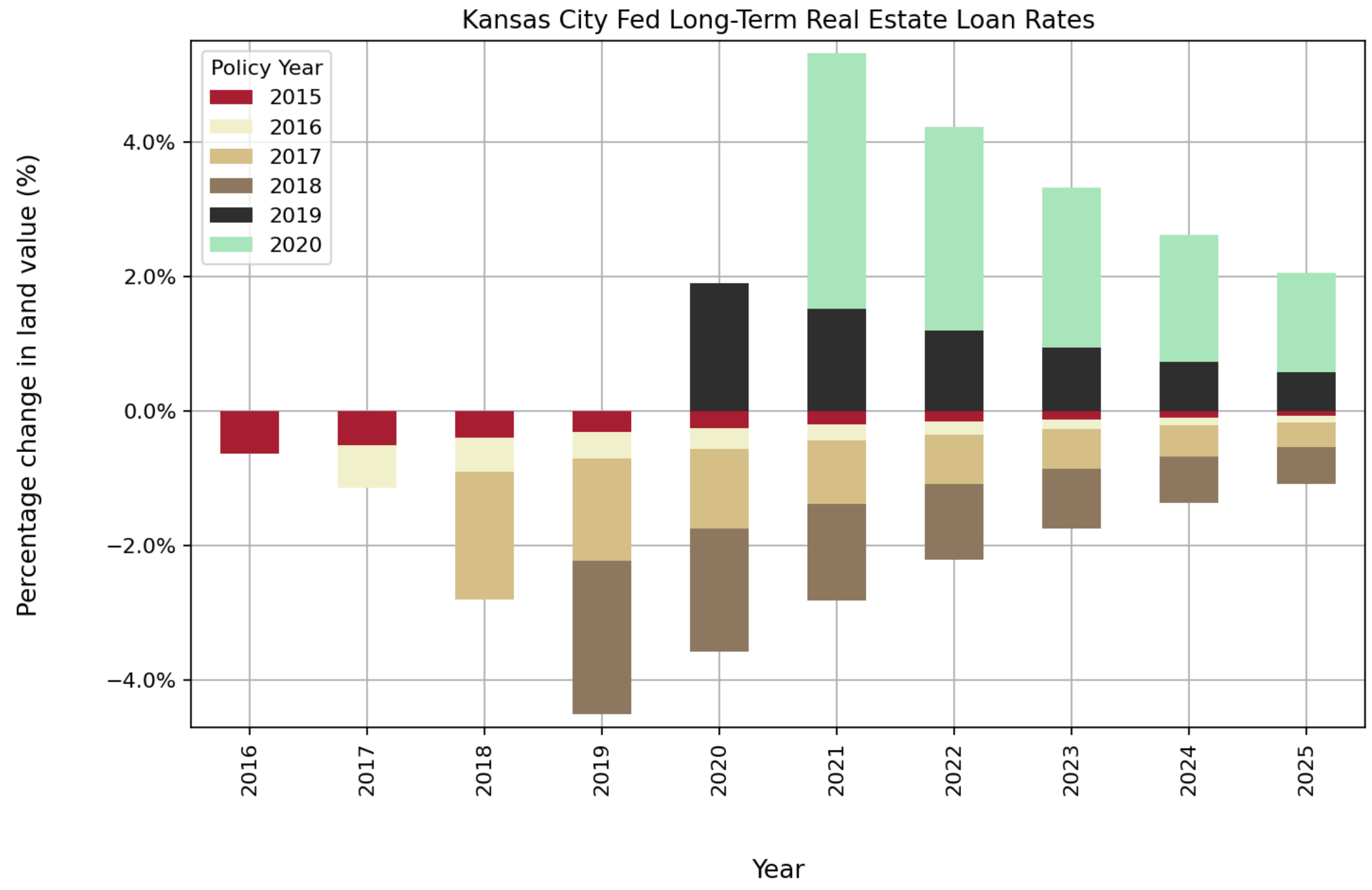


(B: Chicago Fed loan rates)

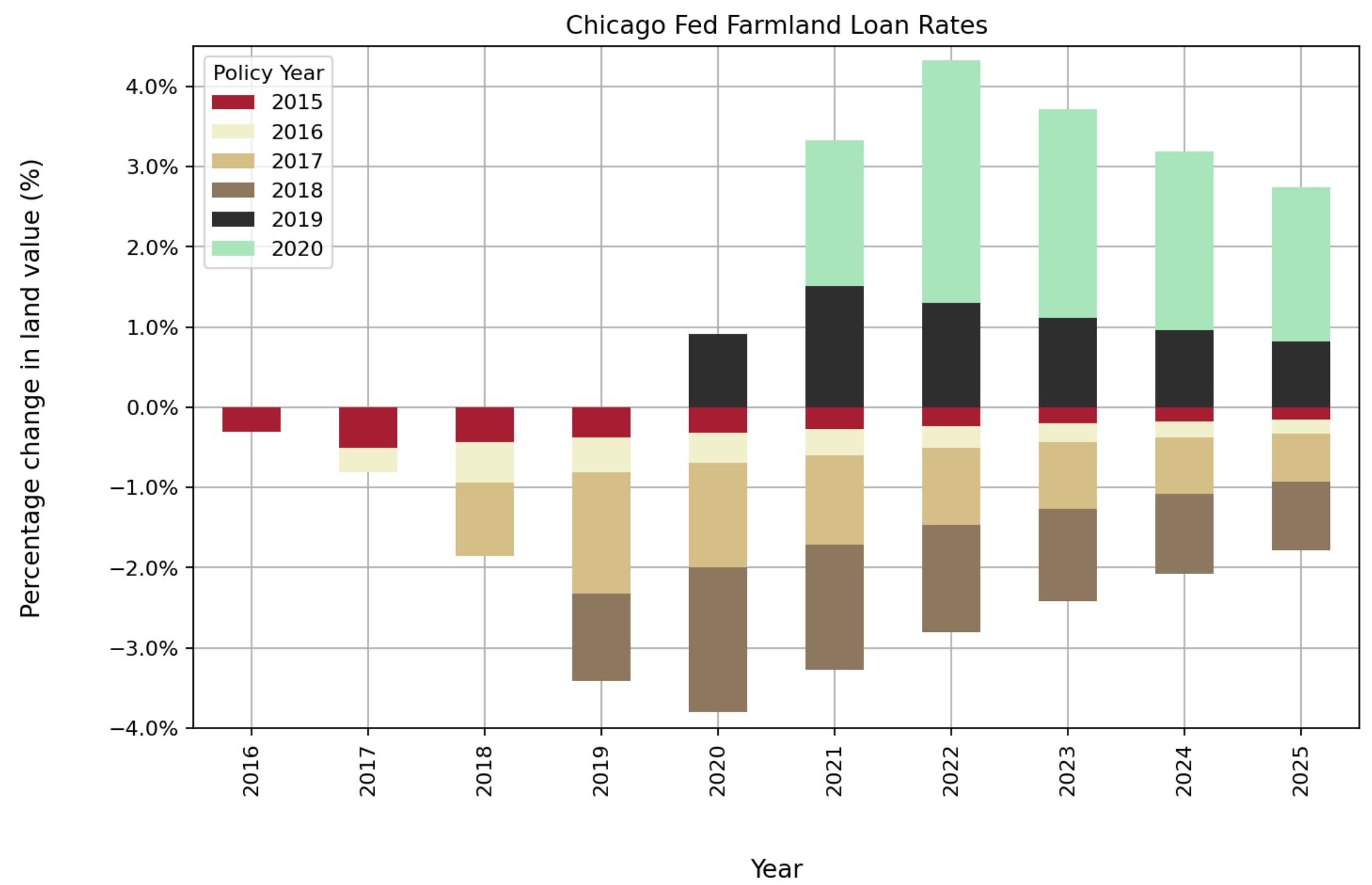


(C: CMT-10 treasury rate)

10-Year CMT Rate

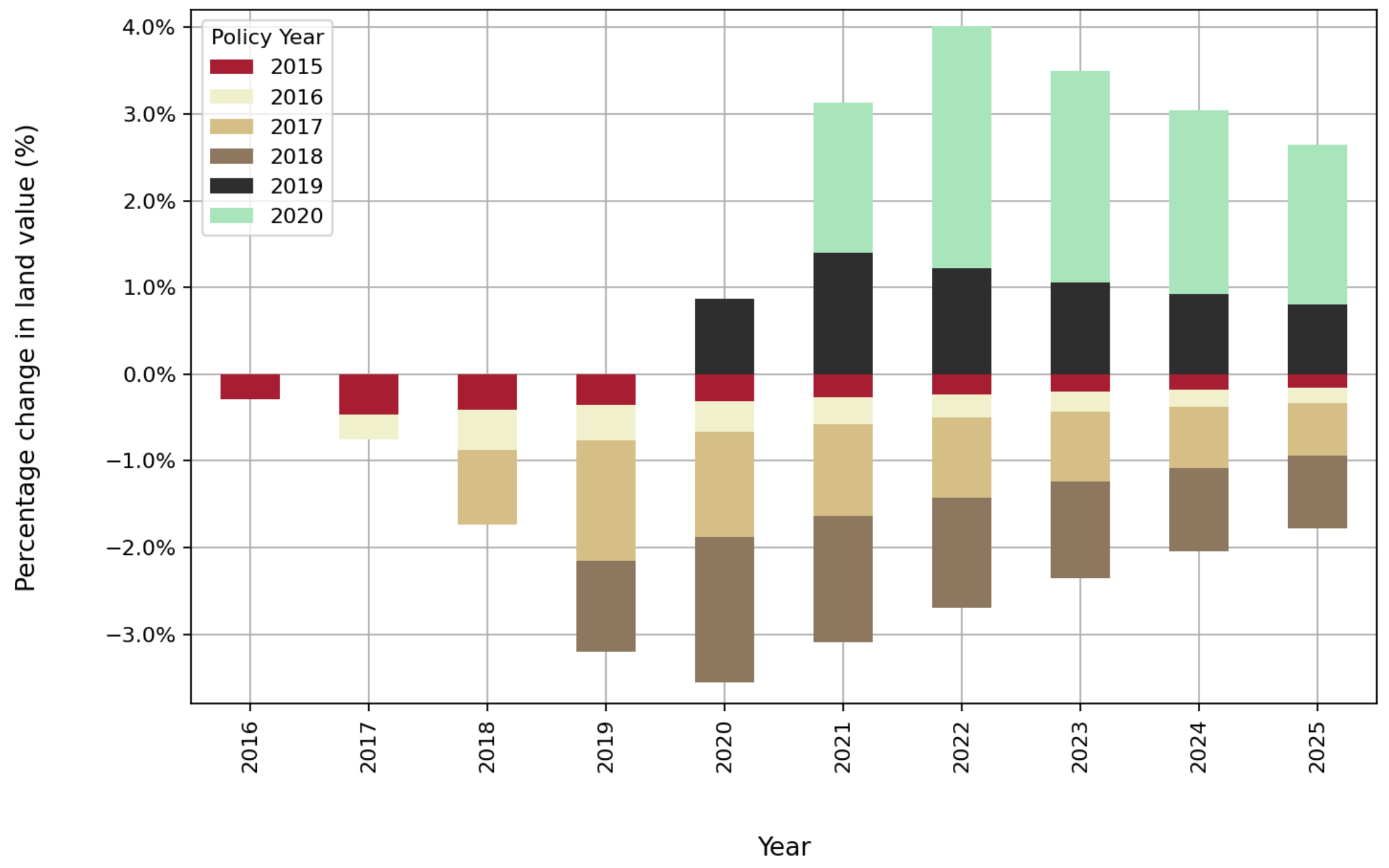


(D: CMT-1 treasury rate)

1-Year CMT Rate

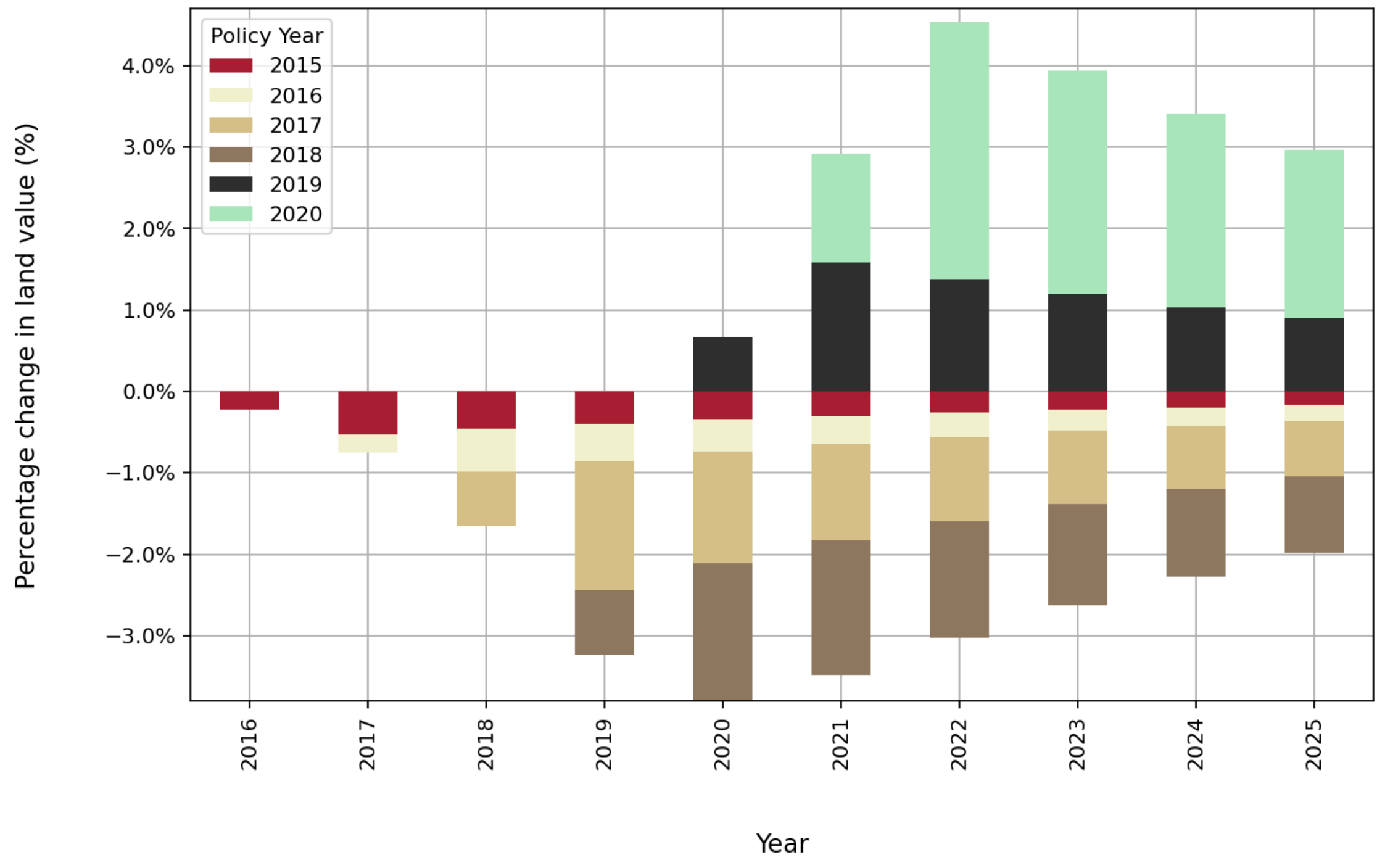


Figure A4. The median lag lengths and the short- and long-term impacts of interest rate moves on I-States using the ARDL $(2,2 ; 3)$ model

(A: Median lag length for the two-lag ARDL model)

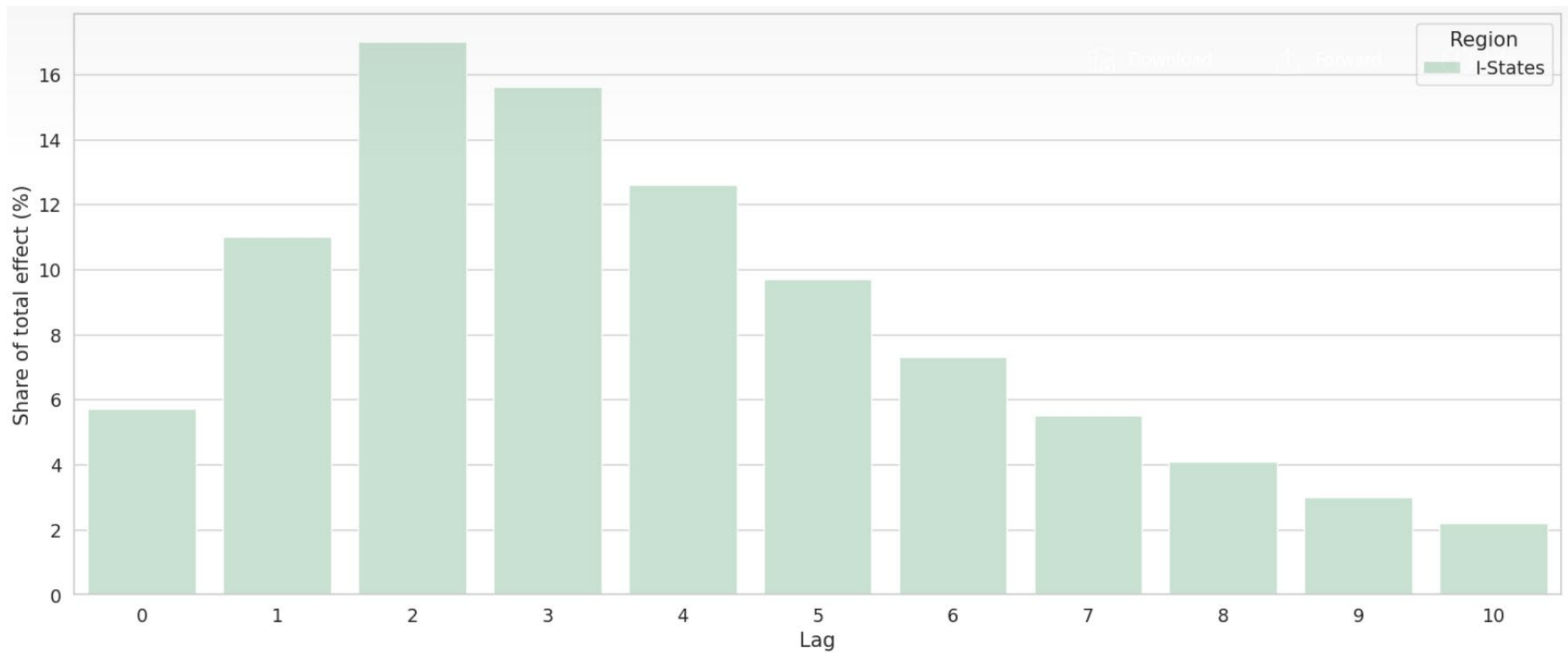


(B: Short- and long-term capitalization effects of federal funds rate changes)

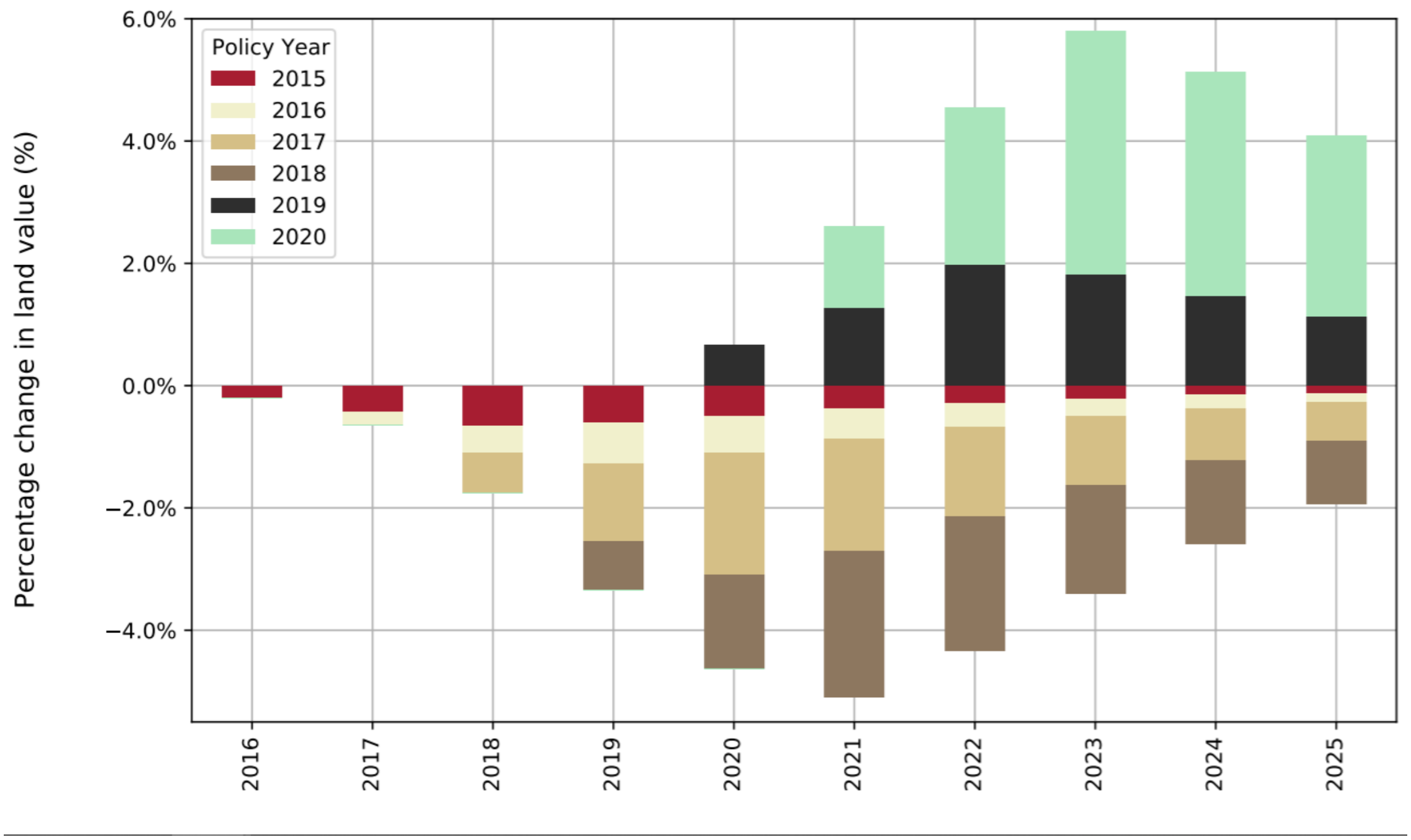

